\title{
Healthy Cattle Microbiome and Dysbiosis in Diseased Phenotypes
}

\author{
Alaa Khalil ${ }^{1, *} \mathbb{C}$, Aamina Batool $^{2}$ and Sania Arif ${ }^{3}$ \\ 1 Department of Animal Science, Georg-August-University, Burckhardtweg 2, 37077 Goettingen, Germany \\ 2 Faculty of Life Sciences, University of Central Punjab, Lahore 54000, Pakistan; aaminabatool.9@gmail.com \\ 3 Department of General Microbiology, Institute of Microbiology and Genetics, Georg-August-University, \\ Grisebachstraße 8, 37077 Göttingen, Germany; sarif@gwdg.de \\ * Correspondence: akhalil2@gwdg.de
}

Citation: Khalil, A.; Batool, A.; Arif, S. Healthy Cattle Microbiome and Dysbiosis in Diseased Phenotypes. Ruminants 2022, 2, 134-156. https:// doi.org/10.3390/ruminants2010009

Academic Editors: Ceferino M. López Sández and Silvia Preziuso

Received: 28 September 2021

Accepted: 10 February 2022

Published: 23 February 2022

Publisher's Note: MDPI stays neutral with regard to jurisdictional claims in published maps and institutional affiliations.

Copyright: () 2022 by the authors. Licensee MDPI, Basel, Switzerland. This article is an open access article distributed under the terms and conditions of the Creative Commons Attribution (CC BY) license (https:// creativecommons.org/licenses/by/ $4.0 /)$.

\begin{abstract}
Cattle farming is an ancient practice, with roots in the early Neolithic era that has retained a major status in the food industry, with global beef market revenue amounting to \$385.7B (as of 2018). Hence, cattle maintenance is essential for catering to the nutritional requirements of modern civilization. This extensive review aims to provide a holistic overview of the cattle microbiome, analyzing the native microbial composition within the respiratory tract, gastrointestinal tract, reproductive tract, and skin of cattle. The dysbiosis associated with various diseases such as bovine respiratory disease, bovine digital dermatitis, mastitis, Johne's disease, uterine diseases (metritis and endometritis), and metabolic disorders (ruminal acidosis and ketosis) have been discussed. Moreover, various nonantibiotic microbial therapies including phage therapy, prebiotics, and probiotics have been examined as potential means to reduce disease-associated dysbiosis. In general, this review highlights the importance of the microbiome in the maintenance of health in cattle and its potential in alleviating bovine diseases, with an aim to enhance cattle health and production.
\end{abstract}

Keywords: microbiome; cattle; Johne's disease; dysbiosis; mastitis

\section{Introduction}

Microbiome encompasses an interactive and dynamic micro-ecosystem, established by the genetic elements, structures, and metabolites of characteristic microbiota. The microbiota inhabits diverse ecological niches, including eukaryotic hosts. In eukaryotic host environments, the importance of the microbiome in the maintenance of physiological functionality has been indicated as a neglected niche by many researchers [1]. The potential influence of the microbiome on cattle growth and the immune system has been thoroughly investigated [2]. The commensal microbiota confers beneficial effects to animal health through various mechanisms; such as helping to digest the otherwise indigestible plant fiber [3]. Moreover, it provides the host with nutrients and energy sources (volatile fatty acids) [4], building units (carbohydrates, peptides, lipids) [1,5], and modulates the immune system via cytokines and antibodies [6]. Microbiota creates a physical barrier between pathogens and immune cells, competing with the pathogens for adhesion sites and nutrients $[7,8]$. Moreover, these microbes inhibit pathogenic growth by producing antimicrobial compounds, such as organic acids, hydrogen peroxide, bacteriocins, and biosurfactants $[9,10]$.

The holistic view of the cattle microbiome indicates the colonization of skin, body cavities, and mucosal surfaces, of respiratory, gastrointestinal, and urogenital tracts, by microbial communities [11-14]. The distribution varies throughout these organs, depending on the host factors and distinct physiochemical properties of the colonization site [15]. Although cattle microbiome co-evolves with its host (influenced by inter-microbial interactions, host attributes, and environmental factors) [16], the core functional microbiome in any organism is more conservative [17]. However, during disease conditions, the delicate growth balance of microbial consortium is prone to intrusions, followed by either loss or 
gain of different microbial species, leading to dysbiosis [18]. Dysbiosis may cause or aggravate multiple disease phenotypes in cattle such as Johne's disease, uterine and metabolic diseases (ruminant acidosis) $[19,20]$. To explore the therapeutic and prophylactic role of the cattle microbiome, understanding the microbial composition (particularly associated with health and disease phenotypes) is paramount. This understanding could very well aid in laying out a well-defined microbiome manipulation strategy for better health and production outcomes [21]. Therefore, this review aims at summarizing the natural bacterial microflora associated with a healthy cattle microbiome and how the composition shifts during disease conditions. Alternative therapeutics such as probiotics, prebiotics, and bacteriophages that have proven efficacy in combating dysbiosis have been discussed [22].

\section{Development and Succession of Cattle Microbiome with Age}

Since the microbiota represents a dynamic ecosystem where the host factors play a crucial role in the selection, adaptation, and stabilization of microbial communities, it would be prudent to observe the developmental changes in the microbial consortium throughout the cattle lifespan [23]. Previous studies report significant fluctuations in the microbiome throughout the cattle's lifetime $[17,24]$. These changes could very well be influenced by infant transitions (weaning age, weaning strategy, mode of delivery, and type of milk feeding), as well as environmental factors and host genetics $[25,26]$. Soon after birth, the infant microflora starts to establish and is derived from mother's vaginal, skin and environmental microbiota [27]. It implies that the mode of delivery, either through natural (vaginal) or cesarean section (C-section), could be a deciding factor regarding the initial infant microbiome [26]. Recent studies observed a significant microbiome difference between these two modes of delivery, as vaginal delivery led to higher species richness, evenness, and diversity in human and cattle infants as compared to C-section delivery $[17,28]$. Following vaginal delivery, the species belonging to the phylum Proteobacteria were most abundant in calves' rumen, in addition to the increased relative abundance of gastrointestinal tract-related genera Bifidobacteria and Bacteroides [29] and the vaginal tract-associated genera Prevotella and Butyrivibrio spp. [17] In contrast, the rumen of calves, delivered by C-section, are more likely to be colonized by species from the phylum Firmicutes, and the genera Peptostreptococcus and Dorea. The reduced colonization and low maternal microbial persistence over time in calves after C-section make them more prone to infections [17].

The newborn calves lack a fully functional rumen, as the milk bypasses the rumen, reticulum, and omasum. The milk passes through the oesophageal groove to the abomasum where it is enzymatically digested [30]. In young ruminants shortly after birth, aerobic and facultative anaerobes gradually consume oxygen which contributes to the predominance of the anaerobes in the rumen microbiome [24]. As shown in Figure 1, during the first three days, rumen microbiota is dominated by Proteobacteria, Firmicutes (whereas Streptococcus represents $75 \%$ of the Firmicutes reads), and Bacteroidetes with varying minor contributions of other phyla including Actinobacteria, Fusobacteria, Tenericutes, and Cyanobacteria [24,31]. The microbiome abundance trend shifts from the phylum Proteobacteria (that dominate for the first three days) to Bacteroidetes (that dominate during 3-12 days of age $[24,32,33]$ ). Another prominent microbial transition during early stages to adult development is characterized by the Verrucomicrobiaceae genus Akkermansia decline (from $23-40 \%$ during the early days to $2-4 \%$ at first month) $[17,24]$. Among the minor phyla, Actinobacteria mainly Actinomycetales and Fusobacteria are prominent in the newborns [24]. Taxonomical diversity increases with age, especially upon the introduction of a new fermentation substrate, i.e., solid food [34]. Prevotellaceae family is observed to be the most abundant family in the phylum Bacteroidetes from day 6 to 83 with 31 to $72 \%$ abundance, respectively $[17,24,32]$. 


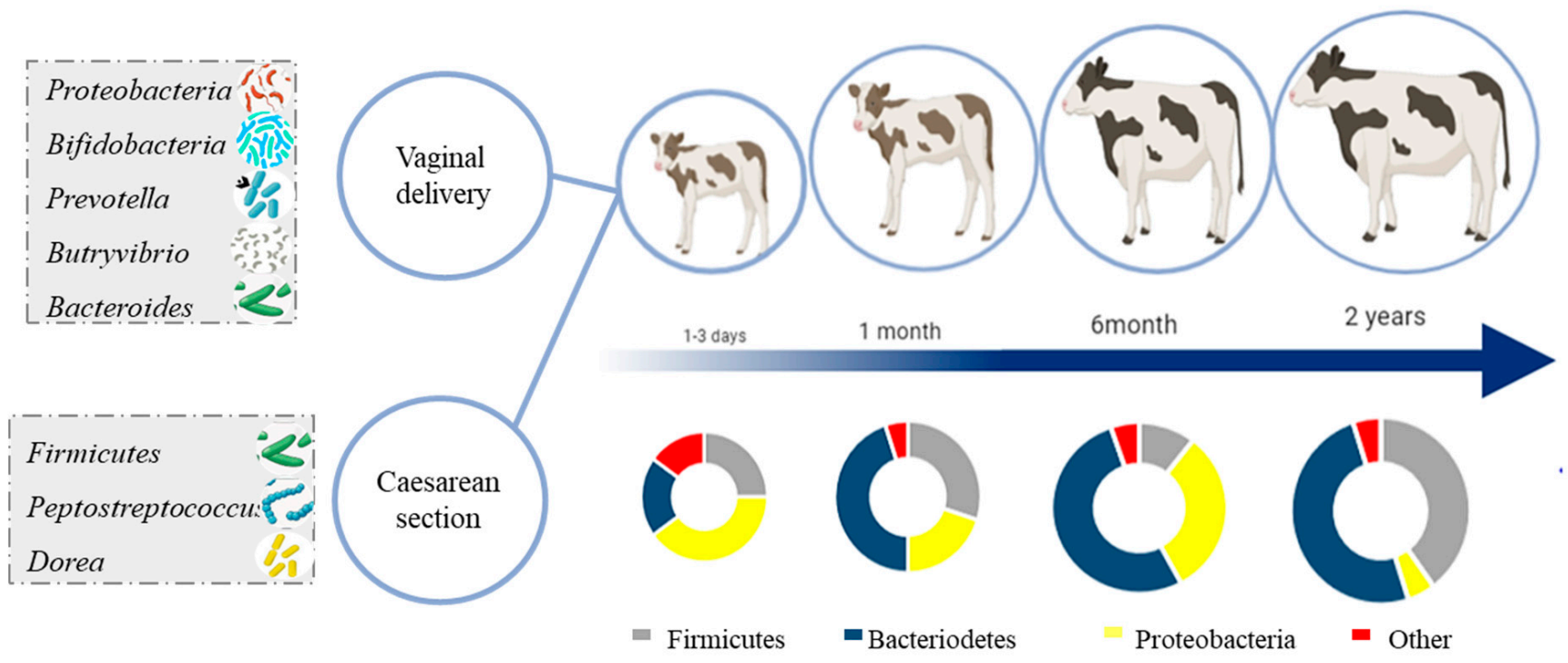

Figure 1. Dynamics of bacterial communities across different ages [24,32].

\section{Healthy Cattle Microbiome Composition}

\subsection{Respiratory Tract Microbiome}

The respiratory tract harbors a distinct microbial make-up within nostrils, nasopharynx, hard plate, oropharynx, tonsils, trachea, and lungs [35]. Overall, a healthy cattle respiratory tract microbiome could be attributed to six phyla, namely Proteobacteria, Firmicutes, Tenericutes, Actinobacteria, Fusobacteria, and Bacteroidetes [36]; although, the relative abundance of each phylum is varied across individual organs. Tenericutes dominated the distal trachea to the lungs, the exception being the secondary bronchi of the left and right caudal lobes, which were colonized mainly by Actinobacteria [35]. Proteobacteria prevailed in the nostrils, nasopharynx, and oropharynx, whereas Firmicutes were extensively present on the floor and hard palate of the mouth and Fusobacteria colonized the tonsils. At the genus level, Mycoplasma, Moraxella, Streptococcus, Fusobacterium, and Streptomyces were the most abundant along the respiratory tract with uneven distribution as following: Mycoplasma predominated the trachea, lung, nostril, and nasopharynx; Streptococcus predominated the floor and hard plate of the mouth; Bibersteinia were localized in oropharynx; and Fusobacterium dominated the tonsils [35].

\subsection{Gastrointestinal Microbiome}

Given the significance of oral health in organisms, extensive studies have been devoted to investigating the human, cat, sheep, and dog oral microbiome [37-39]. Most studies on cattle oral health are limited to dental formulas and diseases, and not much data are available regarding the oral microbiome. Recently, it was reported that the most prevalent genera associated with healthy cattle oral cavity are Arcobacter, Gastranaerophilales, Planifilum, Escherichia-Shigella, Actinobacteria, Burkholderia, and Pseudomonas (Figure 2). Interestingly, studies pertinent to periodontitis reported that healthy samples demonstrate low intra-sample variability and are clustered separately from disease-prevalent samples [40].

\subsection{Rumen Microbiome}

The ruminal stomach is made of four compartments, the reticulum, rumen, omasum (pre-stomach), and abomasum (true stomach) [41]. Being the largest compartment of the stomach, the complexity of the microbial ecosystem allows rumen to utilize fiber-rich diets in addition to complex carbohydrates [42], resulting in the digestion of $60-70 \%$ of the ingested cellulose [1]. Bacteria are the most abundant prokaryotes, making up more than $95 \%$ of the ruminal microbiota at a cellular density of 1010-1011 cells/g [2]. The most abundant phylum in the rumen are Bacteroidetes (with genus Prevotella comprising 
$45-57 \%$ of total $16 \mathrm{~S}$ rRNA sequences and $90 \%$ of Bacteroidetes population), followed by $28 \%$ of phylum Firmicutes. Furthermore, genera Dialister, Succiniclasticum, Ruminococcus, Butyrivibrio, and Mitsuokella represented more than $1 \%$ of the total bacterial genera in the rumen [43].

\subsection{Small Intestine}

The main function of the small intestine is the absorption of protein and carbohydrates [1] and its compartments (duodenum, jejunum, and the ileum) vary in their function and microbial communities. Interestingly, a study reported that phylum Firmicutes were dominant within all sections of cattle gastrointestinal tract except jejunum (Proteobacteria were dominant here). Enterobacteriaceae were highly abundant within the small intestine, while jejunum was enriched by Ruminococcus, Acetitomaculum, and Lachnospiraceae [44]. Compared to the rumen, the relative abundance of the phylum Bacteroidetes significantly decreased (0.4-1.1\%) while that of phylum Firmicutes elevated drastically, reaching up to $80 \%$ of relative abundance. Studies based on low abundance phyla Actinobacteria (6-13\%), Proteobacteria (0.8-5.8\%), and Tenericutes (0.4-4\%) have also been reported. Furthermore, other significant genera pertinent to the small intestine include Ruminococcus, Butyrivibrio, Lactobacillus, Bulleidia, Mogibacterium, Mitsuokella, and Propionibacterium [43].

\subsection{Large Intestine}

Bacterial abundance in the cecum, colon, and rectum is about 1012 to 1014 cells / mL [1] The large intestine plays an important role in water absorption and digestion as $30 \%$ of the cellulose digestion takes place in the large intestine [1,45]. Different regions of the large intestine represent distinct microbial intensity and diversity in the corresponding microbiota. In the cecum, Firmicutes have been the predominant phylum reaching up to $81 \%$ of the total phyla while Bacteroidetes contribute to 18-26\%. Spirochetes, Tenericutes, and Actinobacteria have also been reported in the cecum. Furthermore, Prevotella, Turicibacter, Coprococcus, Ruminococcus, Dorea, Blautia, Clostridium, and Oscillospira have been the most abundant genera in the cecum [43]. Similar to the cecum, the colon contains phylum Firmicutes as $81 \%$ of microbial relative abundance, followed by Bacteroidetes at $21-33 \%$. Moreover, Spirochetes, Tenericutes, Proteobacteria, Actinobacteria, and Fibrobacteres have been in the greatest abundance among the rest of 23 phyla. The most abundant genera were Prevotella, Ruminococcus, Coprococcus, Dorea, Turicibacter, Blautia, Oscillospira, and Parabacteroides [43,46]. Similarly, the rectum has also been dominated by the phylum Firmicutes. Moreover, the genera that dominated the rectum were Clostridium, Roseburia, Osillospira, Succinivibrio, Ruminococcus, Bacteroides, Prevotella, Blautia, Coprococcus, and Turicibacter [47].

\subsection{Reproductive Tract Microbiome}

Reproductive efficiency greatly influences the overall productivity of cattle as well as the regulation of health and homeostasis. From that perspective, the need for understanding the reproductive tract microbiome becomes significant [48]. Despite the availability of advanced next-generation sequencing techniques (NGS), the healthy cattle reproductivetract microbiota are not fully understood due to a lack of definitive research. Insights in the healthy reproductive tract microbiome would greatly improve and influence cattle reproduction, maternal and neonatal therapeutic practices [49].

\subsection{Female Reproductive Tract}

Significant differences in the bovine reproductive-tract microbiome are linked with the type of breed [50], anatomical regions in the tract [13], and physiological status [10]. Four major phyla have been reported by several studies, namely Firmicutes, Bacteroidetes, Proteobacteria $[10,13,50,51]$, and Actinobacteria [13,51]. The predominant genera reported were Aeribacillus, Bacillus, Clostridium, Ruminococcus, Rikenella, Alistipes, Eubacterium, and Prevotella [10,51]. The cattle uterus contains the uterine body and two uterine horns; and each horn has its oviduct [52]. The concept of a sterile uterine system has been challenged 
by several studies [7]. The uterine microbiome exists before the occurrence of pregnancy as the female reaches reproductive maturity, and it is maintained throughout pregnancy. The major phyla colonizing the uterus reported for five pregnant and 10 virgin cows were Firmicutes, Bacteroidetes, and Proteobacteria [8]. Another study by Clemmons et al., 2017 compared the healthy microbiome communities in the bovine vagina and uterus for nonpregnant cows after insemination. They reported that Firmicutes were the most dominant phyla in both uterus and vagina. The next phyla, in order of abundance, were Proteobacteria, followed by Actinobacteria, and Bacteroidetes. At the genus level, the vagina showed the highest abundance of an undetermined genus pertinent to order Bacteroidales. The next in order of abundance were genus 5-7N15 pertinent to family Bacteroidaceae, followed by Oscillospira, Butyrivibrio, Ureaplasma, Campylobacter, Dorea, CF231 (pertinent to family Paraprevotellaceae), Clostridium, Helcococcus, and Corynebacterium. Alternatively, the uterus contained a dominating abundance of Corynebacterium, Ureaplasma, Staphylococcus, Microbacterium, Butyrivibrio, and Helcococcus [13].

\subsection{Bull Reproductive Tract}

Selection of the bulls is a vital practice for the cattle industry [53]. Despite the microbial significance in the maintenance of fertility and reproductive health, the research found on this topic remains nominal. A study published in 2019 investigated the microbiome of the penis and prepuce [54]. According to the authors, the most abundant phyla were Firmicutes, Fusobacteria, Bacteroidetes, Proteobacteria, and Actinobacteria. Community composition was consistent with clustering patterns and low and high diversity clusters were identified at the genera level. For low diversity samples, Bradyrhizobium had constantly been detected, whilst the high diversity samples exhibited multiple genera. The dominant colonizers in the prepuce were Bacteroides, unclassified Ruminococcaceae, Histophilus, and Streptobacillus [55].

\subsection{Skin Microbiome}

Skin is a potent physical barrier against pathogenic invasion, environmental factors, and physical trauma [48]. Interestingly, studies that sought to analyze changes in human and cattle skin microbial communities caused by close environmental contact reported a weak correlation in the characterization of the cattle skin microbiome. Much focus has been reserved for the teat skin microbiome, particularly as it related to raw milk microbial diversity. Some of the major taxa found to be associated with teat skin were Corynebacteriales, Clostridium, Atopobium, Bifidobacteriales, Lachnospiraceae, and Coriobacteriia as well as Pediococcus, Aerococcus, Staphylococcus, Pantoea, Enterobacter, Enterococcus, and Proteobacteria [56,57]. Several commensal microbial species associated with teat skin are not common in milk, indicating a breakdown of microbial flow from teat skin to milk [57]. Ample research has been devoted to the characterization of the microbiome of digits as well [58]. Healthy digits have been characterized by elevated levels of phyla Proteobacteria, Bacteroidetes, and Firmicutes [59-61]. Furthermore, Actinobacteria and Spirochetes have also been detected in healthy digits [59]. A study by Mamuad et al., 2020 indicated two more phyla that preceded the aforementioned phyla in abundance. The study reported Tenericutes and Bacteroidetes, with $14.1 \%$ and $11.8 \%$ mean abundance respectively [61]. The families commonly found in healthy skin belong to Ruminococaceae, Aerococcaceae, Corynebacteriaceae, and Moraxellaceae [60]. 


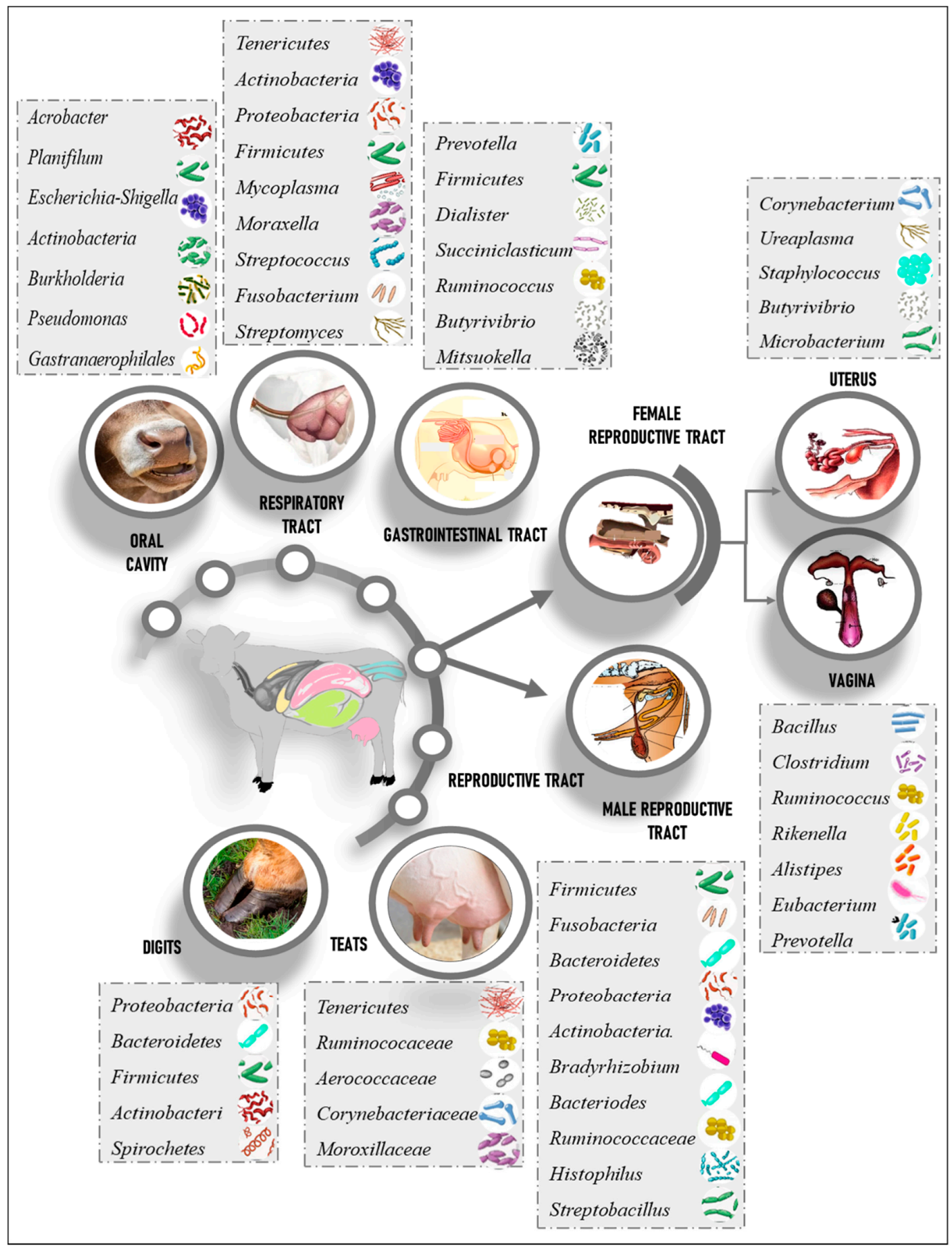

Figure 2. Variation in healthy cattle microbiome at different organs. Predominant bacteria in skin, reproductive organs, oral cavity, gastrointestinal tract, and respiratory tract are shown $[10,13,35,40,51,55-57,60,62]$.

\section{Cattle Diseases Associated with Microbiome Dysbiosis}

\subsection{Bovine Respiratory Disease BRD}

Bovine respiratory disease (BRD) is a complex multifactorial disease associated with host susceptibility, pathogenic load, and environmental stimuli [63]. BRD is a major concern for producers worldwide due to the high treatment costs as well as high morbidity and mortality rate [64]. Among the environmental factors, transportation stress along with temperature fluctuations and ventilation play a crucial role in aggravating the disease [65]. Dysbiosis has been reported to be one of the hallmarks of disease [11]. Disease 
conditions are exacerbated through infections and immune system suppression caused bybovine pestivirus A, bovine orthopneumovirus, and bovine respirovirus 3 [66]. According to previous studies, the most commonly described bacterial communities in BRD comprised of Mycoplasma spp., particularly Mycoplasma bovis, Mannheimia haemolytica, and Pasteurella multocida $[67,68]$. Many studies have also reported the natural abundance of these bacteria in the healthy respiratory tract microbiome. Nevertheless, these species are classified as opportunistic [69] and their relative abundances are higher in diseased animals as compared to their healthy counterparts. For instance, the abundance of Mycoplasma and Mannheimia has increased substantially over time in infected calves, though some studies also report a rise in Moraxella spp., indicating its role in the pathogenesis of BRD [66,67]. Pseudomonas fluorescens abundance has also been significantly higher in BRD-infected calves; however, its contributing role in respiratory disease remains unclear [67]. Recent studies in healthy calves reported the abundance and probiotic effect of Lactobacillus lactis and Lactobacillus casei colonization against $M$. haemolytica growth, which has also been proved in vitro [68] (Table 1).

\subsection{Bovine Digital Dermatitis}

Bovine Digital Dermatitis (DD) is characterized by painful ulcerative lesions that might persist in chronic disease [70] and is identified as a major cause of cow lameness. Being a highly prevalent infectious disease, DD causes major economic losses in dairy herds worldwide and affects animal health, productivity, and welfare [71]. It is a genetic, multifactorial disease, influenced by both environmental as well as pathogenic involvement [72]. Disease pathogenesis is still not fully understood, though several research papers have been published since its first description in 1974 [60]. Several studies have frequently identified spirochetes from Treponema genus as a major pathogen in DD lesions [59,60,72-74]. A distinct six phylogroups were highly associated with the disease and classified as Treponema phagedenis, Treponema medium, Treponema putidum, Treponema denticola, Treponema matophilum, and Treponema paraluiscuniculi groups [75]. Despite the continual presence of Treponema spp. In DD lesions, the DD disease phenotype could not be reproduced by using Treponema pure culture [76]. Other identified microbes included Mycoplasma spp., Fusobacterium necrophorum, Bacteroides spp., Porphyromonas levii [60,73], Prevotella spp., Corynebacterium spp., and Tissierella spp. [59] These pieces of evidence suggested the potential association of these bacteria with the disease pathogenesis as secondary opportunistic pathogens [77]. A metagenomic study by Zinicola et al., 2015, could not detect any viral or fungal DNA in the DD lesions and thus presently, it cannot be linked to the disease $[74,77]$. The positive response against antibiotic treatment also indicated the bacterial nature of the disease [76]. A correlation has been proposed between the main pathogen Dichelobacter nodosus involved in bovine foot rot and DD lesions by several studies $[78,79]$. Nevertheless, this correlation was negated by another study that reported a lack of presence of D. nodosus in Swiss cattle affected by DD [80]. Another study by Krull et al., 2014 stated the presence of D. nodosus in DD lesions but no statistical significance was reported [60]. The Treponema spp. were also observed within the rumen and fecal microbiome of infected cattle [74]. Another study suggested that foremilk and udder cleft skin might be an important reservoir for Trepenoma spp. [81] (Table 1).

\subsection{Mastitis}

Mastitis is characterized by an inflammatory response to the intra-mammary infection that disturbs the physical barrier of the mammary quarters [82]. This disease is a major economic burden on the dairy industry worldwide, affecting animal health and productivity [83]. Mastitis has been classified into two subgroups based on the severity of the disease (clinical and subclinical). Observable physiological changes in the milk and udder are a consequence of clinical mastitis while in subclinical mastitis no symptoms are observed, despite the presence of pathogens [84]. Mastitis's aetiological agent usually has a microbial origin that involves various bacterial species. The 
major pathogens included Staphylococcus aureus, Streptococcus agalactiae, Escherichia coli, Streptococcus dysgalactia, Mycoplasma spp., whilst the minor pathogens were represented by coagulase-negative staphylococci and Corynebacterium spp. [85] Environmental pathogens including Escherichia coli, Klebsiella pneumoniae, Klebsiella oxytoca, Enterobacter aeorogenes, Streptococcus uberis Pseudomonas spp., and Prototheca have also been involved in mastitis pathogenesis $[83,86]$. NGS has made a transition from identifying a single organism to characterizing the aetiological microbiome associated with mastitis infection [87]. Recent studies reported that alteration in the mammary gland microbiome (dysbiosis) is related to mastitis (whether the dysbiosis is a sequence or consequence of mastitis is still a debate) [88-90]. An increased microbial load and relative reduction in bacterial diversity have been reported in mastitis milk [91]. This can be attributed to the increased amount of pathogenic colonization with the progression of infection, accompanied by a reduction in the healthy commensal bacteria. Altering the intra-mammary commensal bacteria has a deleterious effect on mammary gland homeostasis [92]. Shifts in the milk microbiome have been observed in healthy cows and those infected with mastitis. Phylum Firmicutes have dominated the healthy milk and the usual most abundant phyla were Firmicutes, Bacteroidetes, Actinobacteria, and Proteobacteria [88,93]. In contrast, a higher representation of Proteobacteria was over observed in mastitis milk [88]. Hoque et al., 2019 identified 26 unreported strains associated with mastitis, namely the strains belonging to genera Acinetobacter, Pseudomonas, Streptococcus, Corynebacterium Staphylococcus, Enterococcus, Bacillus, and Escherichia [88] (Table 1).

Recent studies suggested that gut microbiome dysbiosis played an important aetiological role in intra-mammary infections (IMI) [94]. In a study by Ma Chen et al., 2018, it was proposed that the intestinal microbiota can induce mastitis. To examine this suggestion, the researchers induced IMI by fecal transplantation from a cow suffering from mastitis to the germ-free mice, which led to the development of mastitis symptoms [95]. Interestingly, a promising result was obtained when probiotics were introduced in mice, parallel with inoculation of the fecal microbiota of infected cattle. A relatively great relief from mastitis symptoms was observed in the probiotics-treated mice group. In this group, a functional shift in the intestinal microbiota was also observed (to a state different from healthy and diseased microbiota), which approved the author's supposition regarding the correlation of intestinal microbiota in mastitis induction [95]. Another supportive investigation revealed that gut dysbiosis could aggravate S. aureus mastitis severity and the blood-milk barrier permeability. These effects were reversed when fecal microbiota transplant from healthy mice was applied [96]. Nevertheless, the correlation between the gut microbiome and mastitis may also be influenced by other factors. One study found out that the overproduced lipopolysaccharides (LPS) by the rumen, moved into the blood and disturbed the blood-milk barrier by accumulating in the mammary glands. Consequently, inducing IMI in subacute rumen acidosis (SARA) infected cows, and increases the severity of mastitis infection [94]. Ruminal short-chain fatty acids (SCFAs) have a protective effect on the blood-milk barrier, and therefore against IMI [97] (Table 1).

\subsection{Johne's Disease}

Johne's disease is characterized by persistent diarrhea that leads to malnutrition, emaciation, and significant economic losses in the livestock industry worldwide $[98,99]$. Johne's disease is caused by slow-growing non-motile mycobacteria-Mycobacterium avium subsp. Paratuberculosis (MAP) [100]. MAP is also being investigated in correlation with human Crohn's disease [99,101-103]. The pathological similarities between Johne's and Crohn's disease affirmed these speculations [104]. Recent studies suggested that gastrointestinal microbiome dysbiosis facilitated MAP infection and aggravated disease severity $[19,105]$. However, a very limited number of investigations on cattle have been reported so far(Table 1).

A study by Fecteau et al., in 2016 compared the fecal microbial communities between MAP infected, exposed, and negative controls. A distinct bacterial community has been observed in the MAP infected group compared to negative and exposed samples (which 
showed similarity to each other). A relative increase in the phylum Actinobacteria and Proteobacteria along with a significant decrease in the phylum Bacteroidetes and Firmicutes abundance was observed. Interestingly, the genus Arthrobacter has dominated the phylum Actinobacteria in all positive samples [105].

Another study investigated the fecal and ileal microbiota during early infection with MAP. The fecal microbiota showed a relative decrease in the genera Verrucomicrobia and Akkermansia. Planococcaceae and Paraprevotellaceae showed higher abundance in the infected samples. Analysis of ileal microbiota showed less abundance of phylum Proteobacteria in MAP infected calves. Moreover, changes in the microbiome induced functional changes in its metabolites, thus an increased level of metabolism was observed in MAP negative calves. However, increased lysine and histidine metabolism pathways have been associated with MAP infection [19] (Table 1).

\subsection{Uterine Diseases}

Metritis and endometritis are the most important postpartum uterine diseases, affecting up to $40 \%$ of dairy cattle $[106,107]$. Uterine diseases are a major economic concern directly affecting animal health, milk production, and reproductive performance [108]. Metritis is an inflammation of the uterine wall, which is characterized by systematic signs of illness. The symptoms, such as fever and toxemia usually occur during the first 21 days after parturition [109]. Endometritis is an inflammation in the inner lining of the uterus without signs of systematic illness, it can occur during or after 21 days post-partum. Endometritis is classified into clinical and subclinical types $[109,110]$. Uterine diseases are multifactorial where environmental factors affect the occurrence of the disease and host defense plays an important role against bacterial pathogenesis [111]. Cow uterus is exposed to bacterial contamination during calving and up to two weeks postpartum. A healthy cow immune system can resist pathogenic colonization. However, failure to resist a pathogenic colonization leads to disease progression [112]. Several risk factors, including parity, dystocia, retinal placenta, abortion, twins, and calving season, play a role in triggering uterine diseases [113]. Culturedependent studies have identified pathogenic bacteria associated with uterine infections from diseased cows. Trueperella pyogenes and Escherichia coli, in addition to gram-negative pathogens Porphyromonas levii, Fusobacterium necrophorum, Prevotella melaninogenica, and Bacteroides spp. were frequently isolated [114-117]. Trueperella pyogenes is usually diagnosed in clinical endometritis $[117,118]$. Escherichia coli is also reported as one of the major pathogens causing uterine infection [119]. Piersanti et al., 2019 reported that these two pathogens can induce Endometritis in the Holstein Friesian model [118]. Porphyromona, Bacteroides, and Fusobacteria have been associated with metritis [111]. A dysbiosis has been reported in the infected uterus, characterized by a decrease in microbial diversity and enhanced loss of heterogeneity [111]. Increased abundance of Bacteroidetes and Fusobacteria and decrease in Proteobacteria were observed in metritis cow $[20,115]$. The ecological interaction between bacteria seems to be important in the development of metritis, such as increased abundance of the genes of Fusobacterium of the Bacteroides spp. is an essential hallmark. Furthermore, Helcococcus, Porphyromonas, and Filifactor were also found to be associated with metritis [115]. Moreover, the uterine microbiota of clinical endometritis (CE) cows exhibited an increased abundance of Fusobacterium, Trueperella, and Peptoniphilus, whilst subclinical endometritis (SE) cows almost lacked the aforementioned phyla [117] (Table 1).

Proteobacteria, Bacteroidetes, and Fusobacteria have been identified as uterine disease risk factors. Cows with retained placenta and healthy cows exhibit the same total bacterial count in the first days postpartum. However, Bacteroidetes and Fusobacteria tend to be in higher abundance after day-7 in the cows with retained placenta, postpartum fever assisted parturition, and twin delivery. Proteobacteria were found to be more abundant in metritis. The author concluded that the total bacterial load and the microbiome composition are associated with specific risk factors of uterine disease [114]. 


\subsection{Metabolic Disorders}

\subsubsection{Ruminal Acidosis}

Ruminal acidosis is a gastrointestinal metabolic disease of dairy cattle. The prognosis predicts intensive feeding of a high carbohydrate diet by cattle, leading to accumulation of short-chain fatty acids, lactic acid, and LPS in the rumen [120]. This results in an extreme drop of rumen $\mathrm{pH}$ reaching $<5.8$ for at least $3 \mathrm{~h}$ in a day [121]. There are two forms of ruminal acidosis; clinical (acute) and subclinical ruminal acidosis (SARA) [122]. Disease sequelae include lameness, liver abscesses, paint brush hemorrhage, weight loss, scouring, and epistaxis apart from deleterious effects on the reproductive system [27,123]. Ruminal acidosis is the most important disorder of the dairy industry as it causes low milk production, low milk protein, and fat leading to huge economic losses [123].

Rumen microbial community alterations are observed in association with rumen acidosis [124]. Severe reduction or elimination is observed in protozoan communities [27]. Rumen bacterial diversity and richness reduction have also been associated with the disease [125]. Changes in Firmicutes to Bacteroidetes ratio have also been reported, resulting in a decrease in Bacteroidetes and cellulolytic bacteria as well as an increase in starch fermenting bacteria [25,126]. Plaizier et al., 2017 reported an equal relative abundance in Firmicutes and Bacteroidetes in the rumen, which indicated a reduction in Bacteroidetes phylum [126].

Several studies evaluated the composition and functional activity of ruminal microbiota challenged with SARA. Microbiome dysbiosis was indicated by a decrease in cellulolytic bacteria including Fibrobacter succinogenes, Ruminococcus albus, Streptococcus bovis, Butyrivibrio fibrisolvens Prevotella bryantii, Selenomonas ruminantium, and Ruminococcus bicirculans in association with the acidotic challenge $[127,128]$. Streptococcus, Lactobacillus Succiniclasticum, and Clostridium levels were increased during ruminal acidosis [31,128]. Enrichment in carbohydrate-, amino acids-, energy-, vitamin co-factor- metabolism pathways in addition to biofilm formation pathways [127] and high concentration of LPS, have also been reported to be associated with SARA. Inflammation induced by ruminal LPS over-activated nuclear factor kappa-B and mitogen-activated protein kinase inflammatory pathways and significantly increased proinflammatory cytokine synthesis [120] (Table 1).

\subsubsection{Ketosis}

Acetonemia is a metabolic disorder of dairy cattle and affects cattle health, fertility, and milk production during the early lactation period. This disorder contributes to a negative energy balance when energy demands exceed energy intake [129,130].

Ketosis often occurs when high glucose demand is fulfilled through adipose utilization as an energy source. However, fat mobilization may increase non-esterified fatty acid concentration in blood [129]. Prolonged periods of high blood concentrations of nonesterified fatty acids can impair liver function, which leads to partial oxidation of nonesterified fatty acids. Consequently, overproduction and accumulation of ketone bodies, predominantly Beta-hydroxybutyrate (BHB), cause ketosis [131]. BHB levels can be used as a biomarker for ketosis diagnosis. Cows experiencing BHB levels higher than $1.4 \mathrm{mmol} / \mathrm{L}$ are usually diagnosed with ketosis [121].

Ketosis can result in less dry matter intake, reduction in milk production, and weight loss. Some cows also develop neurological disorders, excitable uncoordinated, and aggressive behavior. Furthermore, ketosis may be a risk factor for mastitis [132].

Shifts in the microbiome in cows with ketosis have been detected by qPCR, T-RFLP, and 16S rRNA sequencing. An increase in phyla Firmicutes, and Proteobacteria was detected in cows with ketosis. A significant decrease in Euryarchaeota was also reported with elevated levels of A. lipolytica, P. bryantii, M. elsdenii, and Lachnospiraceae [133]. Furthermore, the genus Ruminococcaceae, Methanobrevibacter, Erysipelotrichaceae, and Atopobium were rarefied $[27,133]$ (Table 1). 
Table 1. Significant transitions in the microbiome associated with cattle disease.

\begin{tabular}{|c|c|c|}
\hline Disease & Significant Changes in the Microbiome & Reference \\
\hline Bovine respiratory disease & $\begin{array}{l}\uparrow \text { Mycoplama bovis } \\
\uparrow \text { Mannheimia haemolytica } \\
\uparrow \text { Pasteurella multocida } \\
\uparrow \text { Mycoplasma }\end{array}$ & {$[67,68]$} \\
\hline Mastitis & $\begin{array}{l}\uparrow \text { Staphylococcus aureus } \\
\uparrow \text { Streptococcus agalactiae } \\
\uparrow \text { Escherichia coli } \\
\uparrow \text { Klebsiella } \\
\uparrow \text { Streptococcus dysgalactia, } \\
\uparrow \text { Corynebacterium bovis }\end{array}$ & {$[85,86,88]$} \\
\hline Johnes Disease & $\begin{array}{l}\uparrow \text { Arthrobacter } \\
\uparrow \text { Bacillus } \\
\uparrow \text { Enterococcus } \\
\uparrow \text { Camobacterium } \\
\uparrow \text { Desemzia } \\
\uparrow \text { Trichococcus } \\
\uparrow \text { Planococcaceae } \\
\downarrow \text { Paraprevotellaceae } \\
\downarrow \text { Faecalibacterium } \\
\downarrow \text { Akkermansia }\end{array}$ & {$[19,105]$} \\
\hline Metritis and endometritis & $\begin{array}{l}\uparrow \text { Trueperella pyogenes } \\
\uparrow \text { Escherichia coli } \\
\uparrow \text { Porphyromonas levii } \\
\uparrow \text { Fusobacterium necrophorum } \\
\uparrow \text { Prevotella melaninogenica } \\
\uparrow \text { Bacteroides spp }\end{array}$ & {$[20,111,114,116,117]$} \\
\hline Bovine digital dermatitis & $\begin{array}{l}\uparrow \text { Treponema spp. } \\
\uparrow \text { Fusobacterium spp. } \\
\uparrow \text { Mycoplasma spp. } \\
\uparrow \text { Porphyromonas spp. } \\
\uparrow \text { Prevotella spp. } \\
\uparrow \text { Corynebacterium spp. } \\
\uparrow \text { Tissierella spp. }\end{array}$ & [59] \\
\hline Rumen Acidosis & $\begin{array}{l}\downarrow \text { Bacteroidetes } \\
\downarrow \text { Fibrobacter succinogenes } \\
\downarrow \text { Ruminococcus albus } \\
\downarrow \text { Ruminococcus bicirculans } \\
\downarrow \text { Butyrivibrio fibrisolvens } \\
\uparrow \text { Prevotella bryantii } \\
\uparrow \text { Selenomonas ruminantium } \\
\downarrow \text { Streptococcus } \\
\uparrow \text { Lactobacillus } \\
\uparrow \text { Succiniclasticum } \\
\uparrow \text { Clostridium }\end{array}$ & {$[31,127,128]$} \\
\hline Ketosis & $\begin{array}{l}\uparrow \text { Lachnosparaceae } \\
\uparrow \text { A. lipolytica, } \\
\uparrow P . \text { bryantii } \\
\uparrow \text { M. elsdenii } \\
\downarrow \text { Ruminococcaceae } \\
\downarrow \text { Methanobrevibacter } \\
\downarrow \text { Erysipelotrichaceae } \\
\downarrow \text { Atopobium } \\
\downarrow \text { F. succinogenes } \\
\downarrow \text { Butyrivibrio proteoclasticus } \\
\downarrow \text { Euryarchaeota }\end{array}$ & {$[27,133]$} \\
\hline
\end{tabular}

The direction of the arrows shows either an increase or decrease in the microbial abundance. 


\section{Non-Antibiotics Microbial Therapy}

\subsection{Probiotics}

Probiotics are live microorganisms associated with human and animal health that confer a beneficial effect on health when administrated in sufficient quantities [134]. Probiotics can exert their beneficial effects through various mechanisms [9]. They can modulate the host-microbiota by competing with pathogens over the adhesion sites and nutrients [135]. Moreover, probiotics maintain intestinal homeostasis, improving barrier function [136]. Furthermore, they can produce antimicrobial metabolites, including lactic acid, diacetyl, and antimicrobial peptides, such as bacteriocins that inhibit competing bacteria [137]. In other cases, probiotics can directly interact with the host cells to modulate the immune system $[138,139]$. The most common microorganisms in probiotics are safe, food-grade bacteria related to genera lactic acid bacteria (LAB), Lactobacillus, and Bifidobacterium [140]. Apart from them, enterococcus and streptococcus form part of probiotics as well [141].

Due to the significance of rumen acidosis in dairy cattle, studies infusing probiotics to treat rumen acidosis were a reasonable choice. Goto et al., 2016 reported that introducing a probiotic cocktail (Miyarisan Pharmaceutical Co., Ltd., Tokyo, Japan) including L. plantarum, E. faecium, and C. butyricum for seven days could improve the $\mathrm{pH}$ and lactic acid level [142]. Yeast has also been incorporated within probiotics in cattle as various studies provide sufficient evidence of its beneficial impact against ruminal acidosis [124,127]. Mohammed et al., 2017 reported that Saccharomyces cerevisiae supplementation could reduce subacute rumen acidosis, but it did not reduce acute acidosis [124].

In line with the global efforts to reduce antibiotics usage, researchers have applied probiotics as a potential alternative approach for preventing and controlling mastitis $[143,144]$. LAB-based probiotics have successfully stimulated the host immune response that may get approved as non-antibiotic mastitis therapy [9]. A study by Pellegrino et al., 2017 investigated the immunomodulatory effect of L. perolens CRL1724 and L. lactis subsp. lactis CRL1655. When inoculated in healthy cows during the dry-off period, the study demonstrated an increase in immunoglobulin (Ig) G in milk and blood samples. They were able to recognize probiotics against $S$. aureus isotopes which could prevent mastitis infection during the dry-off period [145]. Another study conducted by Souza et al., 2018 showed that against S. aureus infection, L. casei BL23 exhibited anti-inflammatory properties on infected bovine mammary epithelial cells and did not obstruct the induction of host cell defensins [146]. A study by Wallis et al., 2018 assessed 13 LAB strains for their ability to form biofilms, producing a barrier against the pathogens and adhere to bovine glandular mammary epithelium. The biofilm formation and adherence were observed in all the strains, showing strain dependency $[9,147]$. Another study by the same group investigated the ability of five LAB strains to remove and replace the biofilm formed by pathogenic staphylococci. All five strains were able to remove the staphylococcal biofilm [148]. To assess the potential probiotic potential of Lactococcus lactis LMG 7930, Armas et al., 2017 examined its in vitro potential against ten mastitis-causing pathogens. The strain showed antagonistic properties against many pathogens such as S. agalactiae and S. aureus strains. Interestingly, the probiotic strain was adhesive to bovine mammary epithelial cells. Although the probiotic strain tends to decrease the internalization of some pathogenic strains, it did not significantly affect pathogen invasion. The author suggested further studies to assess strain safety and efficiency in the field [149]. Another probiotic combination by Pellegrino et al., 2019 to bovine teat canal epithelial cells (BTCEC) selected two strains, lactis subsp. lactis CRL 1655 and Lactobacillus perolens CRL 1724 based on their adhesion patterns and their ability to co-aggregate and inhibit the pathogenesis. The characteristics of these two strains suggested that they may be good candidates for mastitis prevention during the dry-off period [150]. Yu et al., 2017 compared a commercial disinfectant against a probiotic disinfectant of L. plantarum IMAU80065 and IMAU10155 combination. The study showed a gradual decrease in the SCC (somatic cell count; an indicator of milk quality) following the cleaning protocol. Moreover, it was lower in the LAB group than the commercial disinfectant. The complete $16 \mathrm{~S}$ rRNA sequencing of raw milk samples revealed 
substantial diversity in microbial make-up within samples. The authors suggested that probiotic disinfectants can replace chemical disinfectants [151].

Additionally, LAB has been evaluated as a potential preventive method against upper respiratory tract infection (bovine respiratory disease) caused by the M. haemolytica associated pathogen cluster $[59,80]$. In a study by Amat et al., 2020 inter-nasal inoculations with L. amylovorus, L. buchneri, L. curvatus, and L. paracasei, isolated from healthy calves, had been done to investigate their longitudinal effect on the nasopharyngeal microbiome. A significant decrease in $M$. haemolytica, because of the colonization resistance had been reported [36,152]. Another promising study introduced Dietzia spp. as a potential probiotic to inhibit Mycobacterium avium subsp. Paratuberculosis (MAP) and Johne's disease in vitro [153]. The susceptible calf, following MAP infection, had been administered probiotics to impede the development of Johne's disease. For this study, Dietzia subsp. C79793-74 was added to antibiotic-free milk feed for 60 days. None of the ten treated calves developed the symptoms as they aged, in contrast to the untreated group in which seven out of eight developed MAP symptoms. Moreover, a group was treated with a combination of Dietzia and tetracycline, as Dietzia has proven sensitivity to tetracycline contamination. This group also exhibited a high infection rate (six out of eight were infected) which signified the need for good practices along with probiotic administration [154].

Metritis affects up to $40 \%$ of the dairy herd and is usually treated with antibiotics [155]. However, recently, the intravaginal introduction of several LAB strains has been used to prevent or reduce the incidence of postpartum uterine infections [156]. As reported by Deng et al., 2015, the intravaginal administration of a cocktail of LAB composed of Lactobacillus sakei FUA 3089, Pediococcus acidilactici FUA 3138, and FUA 3140 resulted in a lower uterine infection and an overall improvement in local and systematic immune response [157]. Another study suggested that the LAB combination consisting of Lactobacillus rhamnosus, Pediococcus acidilactici, Lactobacillus reuteri, and Lactobacillus sakei showed reduced inflammation in the uterus against endometrium inflammation and E. coli infection [158,159].

Calf diarrhea has a high incidence, especially in the first four weeks of a calves' life, resulting in a high mortality and morbidity rate [160]. Long-term, broad-spectrum antibiotics have conventionally been applied as therapy for the disease [161]. However, probiotic research has been implemented recently for preventing and controlling the disease. Renaud et al., 2019 reported a reduction in the duration of diarrhea in calves treated with multispecies probiotic bolus (MSP). MSP contained Pediococcus acidilactici, Lactobacillus acidophilus, Lactobacillus casei, Enterococcus faecium, Bifidobacterium bifidum, peptide extract, enzyme blend, killed yeast extract, dried whey, and natural flavors. The authors recommended further investigations to assess clinical and economic relevance [162].

Another study administrated fermented milk with Lactobacillus murinus CRL 1695, Lactobacillus mucosae CRL 1696, Lactobacillus johnsonii CRL1693, and Lactobacillus salivarius CRL 1702 to treat calves. Significantly low mortality and morbidity rates were reported in calves treated with fermented milk and LAB as compared to the control group. However, the viable bacterial number showed no difference between the two groups [163]. The study by Fukuda et al., 2019 examined a commercial probiotic product (Bio Three for animal, Toa Pharmaceutical Co., Ltd., Tokyo, Japan) comprised of Bacillus mesentericus, Clostridium butyricum, and Enterococcus faecalis, orally administrated for eight days. The antibiotic-treated group was medicated with ampicillin (Kyritsuseiyaku, Tokyo, Jaban) for the first five days, followed by kanamycin sulfate (Meiji Seika Co., Tokyo, Japan) administration till the eighth day. The results showed no significant differences in fecal score between the two treatment regimes, leading to the confirmation that probiotics can be an alternative therapy to antibiotic treatment [161], the main points are summarized in Table 2. 
Table 2. Important probiotic combinations against disease treatment.

\begin{tabular}{|c|c|c|}
\hline Disease & Probiotic Combination & Reference \\
\hline \multirow[t]{2}{*}{ Rumen acidosis } & L. plantarum, E. faecium, and C. butyricum & [142] \\
\hline & Saccharomyces cerevisiae & [124] \\
\hline \multirow[t]{5}{*}{ Mastitis } & L. perolens CRL1724 and L. lactis subsp. lactis CRL1655 & [145] \\
\hline & L. casei BL23 & [146] \\
\hline & L. rhamnosus ATCC 7469, L. plantarum 2/37, L. Brevis 104/37, L. plantarum 118/37, & {$[148]$} \\
\hline & Lactococcus lactis LMG 7930 & [149] \\
\hline & L. plantarum IMAU80065 and IMAU10155 & [151] \\
\hline \multirow[t]{3}{*}{ Bovine respiratory disease } & L. amylovorus, L. buchneri, L. curvatus, and L. paracasei, & {$[36,152]$} \\
\hline & Dietzia spp. & [153] \\
\hline & Dietzia subsp. C79793-74 & [154] \\
\hline \multirow[t]{2}{*}{ Metritis } & Lactobacillus sakei FUA 3089, Pediococcus acidilactici FUA 3138, and FUA 3140 & [157] \\
\hline & $\begin{array}{l}\text { Lactobacillus rhamnosus, Pediococcus acidilactici, Lactobacillus reuteri, } \\
\text { and Lactobacillus sakei }\end{array}$ & [158] \\
\hline \multirow[t]{3}{*}{ Calf diarrhoea } & $\begin{array}{l}\text { Pediococcus acidilactici, Lactobacillus acidophilus, Lactobacillus casei, Enterococcus } \\
\text { faecium, and Bifidobacterium bifidum }\end{array}$ & [162] \\
\hline & $\begin{array}{l}\text { Lactobacillus murinus CRL 1695, Lactobacillus mucosae CRL 1696, Lactobacillus } \\
\text { johnsonii CRL1693, and Lactobacillus salivarius CRL } 1702\end{array}$ & [163] \\
\hline & Bacillus mesentericus, Clostridium butyricum and Enterococcus faecalis & [161] \\
\hline
\end{tabular}

\subsection{Phage Therapy}

Bacteriophages are viruses acting as intracellular parasites that infect bacteria to replicate within the bacterial cell [164]. The phages can replicate through either the lytic (virulent) or lysogenic (temperate) cycle. These mechanisms play a paramount role in phage therapeutic potential. In the lytic cycle, the virus infects the bacteria and kills the cell [165], whereas, in the lysogenic cycle, the virus can either lysogenize the host cell by integrating its genome into the host genetic material or move to the lytic cycle [166]. The phages are extremely diverse in nature [167], and are thus highly specific in infecting their bacterial hosts [168].

In cattle, bacteriophages have been an attractive alternative to antibiotic usage, as investigated by many researchers [169]. Many in vitro and mouse models show promising results for bacteriophage therapy potential. However, a few clinical studies have been conducted [170]. The phages have been widely introduced against mastitis pathogens such as staphylococcus, E. coli, and Streptococci [144]. Studies on utilizing bacteriophages for treating mastitis caused by S. aureus were reported on the lytic phage SA isolated from purified sewage water to be active against six $S$. aureus strains out of 13 . The highest lytic activity was recorded at $\mathrm{pH} 7$ at $37^{\circ} \mathrm{C}$ [171]. In another study, SA phage exhibited a relatively narrow host range against $10 \mathrm{~S}$. aureus strains compared to SA2 and SNAF phages. Remarkably, phage SNAF exhibited a significant growth reduction in S. aureus compared to SA and SA2 phages [172]. The lytic activity of the SAJK-IND phage reached $100 \%$ against $S$. aureus isolated from mastitis milk, as reported by Ganaie et al., 2018. However, using only MSP exhibited just $40 \%$ lytic activity against the isolates [173]. Another study investigated a mixture of three phages, STA1.ST29, EB1.ST11, and EB1.ST27 against S. aureus from pasteurized as well as raw bovine mastitis milk. The results reported that the bacteriophage mixture significantly reduced S. aureus in the pasteurized milk [174].

Various laboratory models have been used to evaluate the effectiveness of bacteriophages as a treatment in many studies. Iwano et al., 2018 reported that the lytic phage ФSA012 and TSA039 were effective against 93 S. aureus strains and six MRSA strains. Furthermore, studies investigated the effectiveness of phage SSA012 and ФSA039 in vivo using a mouse model. $\Phi S A 012$ showed higher effectiveness in reducing S. aureus proliferation and consequently mammary gland inflammation [175]. The cocktail bacteriophages are 
more effective than single phage, as reported by a study by Geng et al., 2020, investigating the efficiency of lytic phage cocktail vGSM-A1 and vBSP-A2 in the mouse model [176].

Other studies used bacteriophages against E. coli. Porter et al., 2016 demonstrated the effectiveness of a cocktail of four bacteriophages against $E$. coli through several in vitro tests and reported a significant reduction in E. coli adhesion and intracellular survival. Moreover, the phage inhibited E. coli growth when challenged by $1.6 \times 10^{3} \mathrm{CFU} / \mathrm{mL}$ [177]. A more recent study by Da Silva et al., 2018, evaluated the effect of UVF13 phage against $E$. coli in induced mastitis in a murine model. The result indicated a 10-fold reduction in bacterial load in the phage-treated group [178].

Escherichia coli and Trueperella pyogenes are among the pathogens driving metritis [111]. Despite the effectiveness of bacteriophage therapy against E. coli [178], the intrauterine administration of bacteriophages did not affect the uterine pathogens [170]. However, the administration of UFV13 can reduce the T. pyogenes adhesion and disturb the biofilm formation [179].

The phage-derived endolysins have also been proposed as a potential antimicrobial agent. In a study by Zhou et al., 2017, the lytic enzyme LysK $\Delta$ amidase exhibited a broad lytic activity against 137 methicillin-resistant and susceptible staphylococci isolated from bovine mastitis milk samples and human patients [180]. Another study by Fan et al., 2016 investigated trx-SA1 endolysin isolated from $S$. aureus bacteriophage IME-SA1 as a possible treatment for bovine mastitis. The results showed that trx-SA1 could control mild infection of clinical mastitis [181]. An interesting result had been obtained from one study by Scholte et al., 2018, which used PlyC, peptidoglycan hydrolyzed derived from streptococcus $\mathrm{C} 1$ bacteriophage against streptococcus uberis cell wall. The study reported that a low dose of PlyC $1.0 \mu \mathrm{g} / \mathrm{mL}$ can induce lytic activity [182].

Bacteriophages have also been used against $M$. haemolytica, a bacterium that is implicated in bovine respiratory disease pathogenesis. However, none of the studies have reported a promising result against $M$. haemolytica [36].

\subsection{Prebiotics}

Prebiotics are defined as organic nutrients that are indigestible by an animal's upper gastrointestinal tract enzymes but can be digested by one or a limited cohort of gut bacteria and consequently increase their growth and activity. The cumulative effect is an improvement of the host's health $[183,184]$. The most used prebiotics in animals are mannooligosaccharides, fructo-oligosaccharides, and trans-galacto-oligosaccharides. Prebiotics can reduce the attachment of pathogenic bacteria and improve the immune response in cattle [185]. In a study by Grispoldi et al., 2017, the introduction of prebiotics in the Holstein Friesian diet resulted in the reduction of E. coli prevalence [186].

\section{Future Perspectives}

In this review, we endeavour to summarize the microbiota composition and diversity related to cattle niches, as well as its contribution to animal health and production. The commensal microbiota composition is directly affected by various environmental and host factors, for instance, the initial infant microflora is derived from the mother's vaginal, skin, and environmental microbiota [27] while the rumen of calves, delivered by C-section, are more likely to be colonized by species from the phylum Firmicutes instead of Proteobacteria $[17,28]$. It implies that characterization of native colonized microbiome should be analyzed in relation to the potential microbial sources such as water, feed, soil, air, animal handling conditions, etc., and the host characters to be considered are cattle age, breed, immunity, etc. The association studies considering more variables would sort out a similar set of phylogenetic and functional biomarkers among consensus microbiome for a specific niche or organ. For analysis of complete microbiome, microbiome-wide association studies (MWAS) can be undertaken with reference to select the host and environmental parameters [1]. 
Moreover, the lack of consistency within the reported predominance of bacterial phyla within the healthy cattle microbiome results in ambiguity. This uncertainty points to an inevitable need to establish improved standardized methods for characterizing whole cattle metagenome at the omics level. This characterization will lead to a deeper understanding of conserved functional pathways within varying cattle species around the world. Therefore, substantiating the concept of a standardized probiotics therapy that can be administered alongside traditional therapies for effective treatment. The knowledge based on microbial shifts within diseased and healthy microbiota can be utilized to understand and exploit commensal relationships within various microbes. The healthy microbiota can be selected for their prognostic effect, as candidates for preventive probiotics [6].

In light of the commensal relations within microbiota that generate synergistic benefits for cattle, the researchers must focus on selecting and optimizing the most effective microbial combination. These combinations will relieve dysbiosis during disease conditions. Once these combination therapies are established, their efficacy within clinical trials can be initiated to standardize the dosage, time, and other parameters [187-189].

\section{Conclusions}

The review has aimed to build a case for a combination of prebiotic and probiotic therapies alongside traditional antibiotic medicines. The diseases characterized by dysbiosis are promising targets for such an approach. The bioceutical or nutraceutical therapies have shown physiological benefits in humans already. With a deeper understanding of cattle microbiome prevalence and function, these therapies can be extended to all cattle management systems for improved cattle health and lifespan.

Understanding the cattle microbiome is critical for the maintenance of cattle health and productivity. Holistic knowledge of the cattle microbiome has the potential to generate a myriad of benefits, not limited to economic, therapeutic, industrial setups. Despite the advancements in sequencing technologies, our understanding of the complexities of microbiome diversity and interactions with the host remains superficial. Understanding the native microbial composition within could help in designing preventive and therapeutic approaches against the dysbiosis associated with various diseases. Although the research gaps are filling up rapidly and promising results have been elucidated in several studies pertinent to microbiome manipulation, more research is needed before the microbiome can be exploited for effective disease prevention and treatment strategies. Hence, prolonged, horizontal studies with a large sample size are recommended to provide more precise explanations of the mechanisms influencing microbiome composition, diversity, and function.

Author Contributions: A.K. conceptualized and wrote the original draft. A.B. and S.A. contributed to figures drawing and editing the manuscript. All authors have read and agreed to the published version of the manuscript.

Funding: This research received no external funding.

Institutional Review Board Statement: Not applicable.

Informed Consent Statement: Not applicable.

Data Availability Statement: Not applicable.

Acknowledgments: The authors would like to acknowledge Jens Tetens and Michael Hoppert for their constructive suggestions. We also thank Ahmed Khalil, Osman Abdalmonem and Christoph Ammer-Herrmenau for evaluating the review article.

Conflicts of Interest: The authors declare no conflict of interest. 


\section{References}

1. O'Hara, E.; Neves, A.L.; Song, Y.; Guan, L.L. The Role of the Gut Microbiome in Cattle Production and Health: Driver or Passenger? Annu. Rev. Anim. Biosci. 2020, 8, 199-220. [CrossRef] [PubMed]

2. Cammack, K.M.; Austin, K.J.; Lamberson, W.R.; Conant, G.C.; Cunningham, H.C. RUMINNAT NUTRITION SYMPOSIUM: Tiny but mighty: The role of the rumen microbes in livestock production. J. Anim. Sci. 2018, 96, 752-770. [CrossRef] [PubMed]

3. Firkins, J.; Yu, Z. Ruminant nutrition symposium: How to use data on the rumen microbiome to improve our understanding of ruminant nutrition. J. Anim. Sci. 2015, 93, 1450-1470. [CrossRef] [PubMed]

4. Bergman, E. Energy contributions of volatile fatty acids from the gastrointestinal tract in various species. Physiol. Rev. 1990, 70, 567-590. [CrossRef] [PubMed]

5. Bach, A.; Calsamiglia, S.; Stern, M. Nitrogen metabolism in the rumen. J. Dairy Sci. 2005, 88, E9-E21. [CrossRef]

6. Van den Broek, M.F.; De Boeck, I.; Kiekens, F.; Boudewyns, A.; Vanderveken, O.M.; Lebeer, S. Translating recent microbiome insights in otitis media into probiotic strategies. Clin. Microbiol. Rev. 2019, 32, e00010-e00018. [CrossRef]

7. Karstrup, C.C.; Klitgaard, K.; Jensen, T.K.; Agerholm, J.S.; Pedersen, H.G. Presence of bacteria in the endometrium and placentomes of pregnant cows. Theriogenology 2017, 99, 41-47. [CrossRef]

8. Moore, S.; Ericsson, A.; Poock, S.; Melendez, P.; Lucy, M. Hot topic: $16 \mathrm{~S}$ rRNA gene sequencing reveals the microbiome of the virgin and pregnant bovine uterus. J. Dairy Sci. 2017, 100, 4953-4960. [CrossRef]

9. Krishnan, D.; Al-Harbi, H.; Gibson, J.; Olchowy, T.; Alawneh, J. On the use of probiotics to improve dairy cattle health and productivity. Microbiol. Aust. 2020, 41, 86-90. [CrossRef]

10. Laguardia-Nascimento, M.; Branco, K.M.G.R.; Gasparini, M.R.; Giannattasio-Ferraz, S.; Leite, L.R.; Araujo, F.M.G.; Salim, A.C.d.M.; Nicoli, J.R.; De Oliveira, G.C.; Barbosa-Stancioli, E.F. Vaginal microbiome characterization of Nellore cattle using metagenomic analysis. PLoS ONE 2015, 10, e0143294. [CrossRef]

11. Alexander, T. 145 The role of the bovine respiratory microbiota in health and disease. J. Anim. Sci. 2018, 96, 341. [CrossRef]

12. Andersen, T.O. Understanding Rumen Function Using (Meta) Genome-Guided Metaproteomics. Master's Thesis, Norwegian University of Life Sciences, Ås, Norway, 2019.

13. Clemmons, B.A.; Reese, S.T.; Dantas, F.G.; Franco, G.A.; Smith, T.P.; Adeyosoye, O.I.; Pohler, K.G.; Myer, P.R. Vaginal and uterine bacterial communities in postpartum lactating cows. Front. Microbiol. 2017, 8, 1047. [CrossRef] [PubMed]

14. Manus, M.B.; Yu, J.J.; Park, L.P.; Mueller, O.; Windsor, S.C.; Horvath, J.E.; Nunn, C.L. Environmental influences on the skin microbiome of humans and cattle in rural Madagascar. Evol. Med. Public Health 2017, 1, 144-153. [CrossRef] [PubMed]

15. Chu, D.M.; Ma, J.; Prince, A.L.; Antony, K.M.; Seferovic, M.D.; Aagaard, K.M. Maturation of the infant microbiome community structure and function across multiple body sites and in relation to mode of delivery. Nat. Med. 2017, 23, 314-326. [CrossRef] [PubMed]

16. Foster, K.R.; Schluter, J.; Coyte, K.Z.; Rakoff-Nahoum, S. The evolution of the host microbiome as an ecosystem on a leash. Nature 2017, 548, 43-51. [CrossRef]

17. Furman, O.; Shenhav, L.; Sasson, G.; Kokou, F.; Honig, H.; Jacoby, S.; Hertz, T.; Cordero, O.X.; Halperin, E.; Mizrahi, I. Stochasticity constrained by deterministic effects of diet and age drive rumen microbiome assembly dynamics. Nat. Commun. 2020, 11, 1-13. [CrossRef]

18. Wilkins, L.J.; Monga, M.; Miller, A.W. Defining dysbiosis for a cluster of chronic diseases. Sci. Rep. 2019, 9, 1-10. [CrossRef]

19. Derakhshani, H.; De Buck, J.; Mortier, R.; Barkema, H.W.; Krause, D.O.; Khafipour, E. The features of fecal and ileal mucosaassociated microbiota in dairy calves during early infection with Mycobacterium avium subspecies paratuberculosis. Front. Microbiol. 2016, 7, 426. [CrossRef]

20. Jeon, S.J.; Cunha, F.; Ma, X.; Martinez, N.; Vieira-Neto, A.; Daetz, R.; Bicalho, R.C.; Lima, S.; Santos, J.E.; Jeong, K.C. Uterine microbiota and immune parameters associated with fever in dairy cows with metritis. PLoS ONE 2016, 11, e0165740. [CrossRef]

21. Balato, A.; Cacciapuoti, S.; Di Caprio, R.; Marasca, C.; Masarà, A.; Raimondo, A.; Fabbrocini, G. Human microbiome: Composition and role in inflammatory skin diseases. Arch. Immunol. Et Ther. Exp. 2019, 67, 1-18. [CrossRef]

22. Economou, V.; Gousia, P. Agriculture and food animals as a source of antimicrobial-resistant bacteria. Infect. Drug Resist. 2015, 8, 49. [CrossRef]

23. Wang, L.; Zhang, K.; Zhang, C.; Feng, Y.; Zhang, X.; Wang, X.; Wu, G. Dynamics and stabilization of the rumen microbiome in yearling Tibetan sheep. Sci. Rep. 2019, 9, 1-9. [CrossRef] [PubMed]

24. Jami, E.; Israel, A.; Kotser, A.; Mizrahi, I. Exploring the bovine rumen bacterial community from birth to adulthood. ISME J. 2013, 7, 1069-1079. [CrossRef] [PubMed]

25. Clemmons, B.A.; Voy, B.H.; Myer, P.R. Altering the gut microbiome of cattle: Considerations of host-microbiome interactions for persistent microbiome manipulation. Microb. Ecol. 2019, 77, 523-536. [CrossRef] [PubMed]

26. Rinninella, E.; Raoul, P.; Cintoni, M.; Franceschi, F.; Miggiano, G.A.D.; Gasbarrini, A.; Mele, M.C. What is the healthy gut microbiota composition? A changing ecosystem across age, environment, diet, and diseases. Microorganisms 2019, 7, 14. [CrossRef]

27. Cholewińska, P.; Czyż, K.; Nowakowski, P.; Wyrostek, A. The microbiome of the digestive system of ruminants-A review. Anim. Health Res. Rev. 2020, 21, 3-14. [CrossRef]

28. Greenhalgh, K.; Meyer, K.M.; Aagaard, K.M.; Wilmes, P. The human gut microbiome in health: Establishment and resilience of microbiota over a lifetime. Environ. Microbiol. 2016, 18, 2103-2116. [CrossRef]

29. Cunningham, H.C.; Austin, K.J.; Cammack, K.M. Influence of maternal factors on the rumen microbiome and subsequent host performance. Transl. Anim. Sci. 2018, 2, S101-S105. [CrossRef] 
30. Govil, K.; Yadav, D.; Patil, A.; Nayak, S.; Baghel, R.; Yadav, P.; Malapure, C.; Thakur, D. Feeding management for early rumen development in calves. J. Entomol. Zool. Stud. 2017, 5, 1132-1139.

31. McCann, J.C.; Wickersham, T.A.; Loor, J.J. High-throughput methods redefine the rumen microbiome and its relationship with nutrition and metabolism. Bioinform. Biol. Insights 2014, 8, BBI-S15389. [CrossRef]

32. Rey, M.; Enjalbert, F.; Combes, S.; Cauquil, L.; Bouchez, O.; Monteils, V. Establishment of ruminal bacterial community in dairy calves from birth to weaning is sequential. J. Appl. Microbiol. 2014, 116, 245-257. [CrossRef] [PubMed]

33. Yáñez-Ruiz, D.R.; Abecia, L.; Newbold, C.J. Manipulating rumen microbiome and fermentation through interventions during early life: A review. Front. Microbiol. 2015, 6, 1133. [CrossRef] [PubMed]

34. Rey, M.; Enjalbert, F.; Monteils, V. Establishment of ruminal enzyme activities and fermentation capacity in dairy calves from birth through weaning. J. Dairy Sci. 2012, 95, 1500-1512. [CrossRef] [PubMed]

35. McMullen, C.; Alexander, T.W.; Léguillette, R.; Workentine, M.; Timsit, E. Topography of the respiratory tract bacterial microbiota in cattle. Microbiome 2020, 8, 1-15. [CrossRef] [PubMed]

36. Timsit, E.; McMullen, C.; Amat, S.; Alexander, T.W. Respiratory bacterial microbiota in cattle: From development to modulation to enhance respiratory health. Veterinary Clinics. Food Anim. Pract. 2020, 36, 297-320. [CrossRef]

37. Borsanelli, A.; Ramos, T.; Gaetti-Jardim, E.; Schweitzer, C.; Dutra, I. Treponema species in the subgingival microflora of ovine periodontitis. Vet. Rec. 2017, 180, 150. [CrossRef] [PubMed]

38. Holcombe, L.J.; Patel, N.; Colyer, A.; Deusch, O.; O’Flynn, C.; Harris, S. Early canine plaque biofilms: Characterization of key bacterial interactions involved in initial colonization of enamel. PLoS ONE 2014, 9, e113744. [CrossRef]

39. Sturgeon, A.; Pinder, S.; Costa, M.; Weese, J. Characterization of the oral microbiota of healthy cats using next-generation sequencing. Vet. J. 2014, 201, 223-229. [CrossRef]

40. Borsanelli, A.C.; Lappin, D.F.; Viora, L.; Bennett, D.; Dutra, I.S.; Brandt, B.W.; Riggio, M.P. Microbiomes associated with bovine periodontitis and oral health. Vet. Microbiol. 2018, 218,1-6. [CrossRef]

41. Membrive, C.M.B. Anatomy and Physiology of the Rumen. In Rumenology; Millen, D.D., Arrigoni, M.B., Pacheco, R.D.L., Eds.; Springer: Basel, Switzerland, 2016; pp. 1-38.

42. Petri, R.M.; Neubauer, V.; Humer, E.; Kröger, I.; Reisinger, N.; Zebeli, Q. Feed additives differentially impact the epimural microbiota and host epithelial gene expression of the bovine rumen fed diets rich in concentrates. Front. Microbiol. 2020, 11, 119. [CrossRef]

43. Myer, P.; Freetly, H.; Wells, J.; Smith, T.; Kuehn, L. Analysis of the gut bacterial communities in beef cattle and their association with feed intake, growth, and efficiency. J. Anim. Sci. 2017, 95, 3215-3224. [CrossRef] [PubMed]

44. Mao, S.; Zhang, M.; Liu, J.; Zhu, W. Characterising the bacterial microbiota across the gastrointestinal tracts of dairy cattle: Membership and potential function. Sci. Rep. 2015, 5, 1-14. [CrossRef] [PubMed]

45. Harfoot, C. Anatomy, physiology and microbiology of the ruminant digestive tract. In Lipid Metabolism in Ruminant Animals, Christie , W.W., Ed.; Pergamon Press: Oxford, UK, 1981; pp. 1-19.

46. Myer, P.R.; Wells, J.E.; Smith, T.P.; Kuehn, L.A.; Freetly, H.C. Microbial community profiles of the colon from steers differing in feed efficiency. Springerplus 2015, 4, 454. [CrossRef]

47. Durso, L.M.; Miller, D.N.; Schmidt, T.B.; Callaway, T. Tracking bacteria through the entire gastrointestinal tract of a beef steer. Agric. Environ. Lett. 2017, 2, 1-5. [CrossRef]

48. Schmidt, C. Out of your skin. Nat. Biotechnol. 2020, 38, 392-397. Available online: https://www.nature.com/articles/s41587-020-0473-8 (accessed on 5 June 2020). [CrossRef] [PubMed]

49. McClure, M.W. The Vaginal Microbiome Related to Reproductive Traits in Beef Heifers. Master's Thesis, University of Arkansas, Fayetteville, NC, USA, 2018.

50. Nesengani, L.T.; Wang, J.; Yang, Y.; Yang, L.; Lu, W. Unravelling vaginal microbial genetic diversity and abundance between Holstein and Fleckvieh cattle. RSC Adv. 2017, 7, 56137-56143. [CrossRef]

51. Giannattasio-Ferraz, S.; Laguardia-Nascimento, M.; Gasparini, M.R.; Leite, L.R.; Araujo, F.M.G.; de Matos Salim, A.C.; de Oliveira, A.P.; Nicoli, J.R.; de Oliveira, G.C.; da Fonseca, F.G. A common vaginal microbiota composition among breeds of Bos taurus indicus (Gyr and Nellore). Braz. J. Microbiol. 2019, 50, 1115-1124. [CrossRef]

52. Ewies, A.A.; Khan, Z.R. Cattle uterus: A novel animal laboratory model for advanced hysteroscopic surgery training. Obstet. Gynecol. Int. 2015, 2015, 967693. [CrossRef]

53. Wolfe, D. Abnormalities of the bull-occurrence, diagnosis and treatment of abnormalities of the bull, including structural soundness. Animal 2018, 12, s148-s157. [CrossRef]

54. Comizzoli, P.; Power, M. Reproductive microbiomes in wild animal species: A new dimension in conservation biology. In Reproductive Sciences in Animal Conservation; Comizzoli, P., Brown, J., Holt, W., Eds.; Springer: Cham, Switzerland, 2019; pp. 225-240.

55. Wickware, C.L.; Johnson, T.A.; Koziol, J.H. Composition and diversity of the preputial microbiota in healthy bulls. Theriogenology 2020, 145, 231-237. [CrossRef]

56. Frétin, M.; Martin, B.; Rifa, E.; Isabelle, V.-M.; Pomiès, D.; Ferlay, A.; Montel, M.-C.; Delbès, C. Bacterial community assembly from cow teat skin to ripened cheeses is influenced by grazing systems. Sci. Rep. 2018, 8, 1-11. [CrossRef] [PubMed]

57. Verdier-Metz, I.; Gagne, G.; Bornes, S.; Monsallier, F.; Veisseire, P.; Delbès-Paus, C.; Montel, M.-C. Cow teat skin, a potential source of diverse microbial populations for cheese production. Appl. Environ. Microbiol. 2012, 78, 326-333. [CrossRef] [PubMed]

58. Hoffmann, A.R. The cutaneous ecosystem: The roles of the skin microbiome in health and its association with inflammatory skin conditions in humans and animals. Adv. Vet. Dermatol. 2017, 8, 71-83. 
59. Ariza, J.M.; Dopfer, D.; Anklam, K.; Labrut, S.; Oberle, K.; Bareille, N.; Relun, A.; Guatteo, R. Do footbath disinfectants modify the dynamics of the skin microbiota in dairy cattle affected by digital dermatitis? bioRxiv 2019. Available online: https:/ / www.biorxiv.org/content/10.1101/2019.12.20.882787v1.abstract (accessed on 1 May 2020).

60. Krull, A.C.; Shearer, J.K.; Gorden, P.J.; Cooper, V.L.; Phillips, G.J.; Plummer, P.J. Deep sequencing analysis reveals temporal microbiota changes associated with development of bovine digital dermatitis. Infect. Immun. 2014, 82, 3359-3373. [CrossRef] [PubMed]

61. Mamuad, L.L.; Seo, B.J.; Al Faruk, M.S.; Espiritu, H.M.; Jin, S.J.; Kim, W.-I.; Lee, S.-S.; Cho, Y.-I. Treponema spp., the dominant pathogen in the lesion of bovine digital dermatitis and its characterization in dairy cattle. Vet. Microbiol. 2020, 245, 108696. [CrossRef]

62. Holman, D.B.; Gzyl, K.E. A meta-analysis of the bovine gastrointestinal tract microbiota. FEMS Microbiol. Ecol. 2019, 95, fiz072. [CrossRef] [PubMed]

63. Oliveira, V.H.; Agnol, A.M.D.; Fritzen, J.T.; Lorenzetti, E.; Alfieri, A.A.; Alfieri, A.F. Microbial diversity involved in the etiology of a bovine respiratory disease outbreak in a dairy calf rearing unit. Comp. Immunol. Microbiol. Infect. Dis. 2020, 71, 101494. [CrossRef]

64. Pansri, P.; Katholm, J.; Krogh, K.; Aagaard, A.; Schmidt, L.; Kudirkiene, E.; Larsen, L.E.; Olsen, J. Evaluation of novel multiplex qPCR assays for diagnosis of pathogens associated with the bovine respiratory disease complex. Vet. J. 2020, 256, 105425. [CrossRef]

65. Johnson, K.K.; Pendell, D.L. Market impacts of reducing the prevalence of bovine respiratory disease in United States beef cattle feedlots. Front. Vet. Sci. 2017, 4, 189. [CrossRef]

66. Lima, S.F.; Teixeira, A.G.V.; Higgins, C.H.; Lima, F.S.; Bicalho, R.C. The upper respiratory tract microbiome and its potential role in bovine respiratory disease and otitis media. Sci. Rep. 2016, 6, 29050. [CrossRef]

67. Gaeta, N.C.; Lima, S.F.; Teixeira, A.G.; Ganda, E.K.; Oikonomou, G.; Gregory, L.; Bicalho, R.C. Deciphering upper respiratory tract microbiota complexity in healthy calves and calves that develop respiratory disease using shotgun metagenomics. J. Dairy Sci. 2017, 100, 1445-1458. [CrossRef]

68. Timsit, E.; Workentine, M.; van der Meer, F.; Alexander, T. Distinct bacterial metacommunities inhabit the upper and lower respiratory tracts of healthy feedlot cattle and those diagnosed with bronchopneumonia. Vet. Microbiol. 2018, 221, 105-113. [CrossRef] [PubMed]

69. De Oliveira, B.A.F.D.; Gaeta, N.C.; Ribeiro, B.L.M.; Alemán, M.A.R.; Marques, L.M.; Timenetsky, J.; Melville, P.A.; Marques, J.A.; Marvulle, V.; Gregory, L. Determination of bacterial aetiologic factor on tracheobronchial lavage in relation to clinical signs of bovine respiratory disease. J. Med. Microbiol. 2016, 65, 1137-1142. [CrossRef] [PubMed]

70. Staton, G.; Carter, S.; Ainsworth, S.; Mullin, J.; Smith, R.; Evans, N. Putative $\beta$-barrel outer membrane proteins of the bovine digital dermatitis-associated treponemes: Identification, functional characterization, and immunogenicity. Infect. Immun. 2020, 88, e00050-20. [CrossRef] [PubMed]

71. Palmer, M.A.; O'Connell, N.E. Digital dermatitis in dairy cows: A review of risk factors and potential sources of between-animal variation in susceptibility. Animals 2015, 5, 512-535. [CrossRef] [PubMed]

72. Gillespie, A.; Evans, N. Infection reservoirs and transmission of digital dermatitis in the dairy herd. Livestock 2020, 25, 118-124. [CrossRef]

73. Nielsen, M.W.; Strube, M.L.; Isbrand, A.; Al-Medrasi, W.D.; Boye, M.; Jensen, T.K.; Klitgaard, K. Potential bacterial core species associated with digital dermatitis in cattle herds identified by molecular profiling of interdigital skin samples. Vet. Microbiol. 2016, 186, 139-149. [CrossRef]

74. Zinicola, M.; Lima, F.; Lima, S.; Machado, V.; Gomez, M.; Döpfer, D.; Guard, C.; Bicalho, R. Altered microbiomes in bovine digital dermatitis lesions, and the gut as a pathogen reservoir. PLoS ONE 2015, 10, 1-10. [CrossRef]

75. Klitgaard, K.; Bretó, A.F.; Boye, M.; Jensen, T.K. Targeting the treponemal microbiome of digital dermatitis infections by high-resolution phylogenetic analyses and comparison with fluorescent in situ hybridization. J. Clin. Microbiol. 2013, 51, 2212-2219. [CrossRef]

76. Krull, A.C.; Cooper, V.L.; Coatney, J.W.; Shearer, J.K.; Gorden, P.J.; Plummer, P.J. A highly effective protocol for the rapid and consistent induction of digital dermatitis in Holstein calves. PLOS ONE 2016, 11, 1-16. [CrossRef]

77. Vermeersch, A.-S.; Opsomer, G. Digital dermatitis in cattle Part I: Factors contributing to the development of digital dermatitis. Vlaams Diergeneeskd. Tijdschr. 2019, 88, 247-257. [CrossRef]

78. Knappe-Poindecker, M.; Gilhuus, M.; Jensen, T.K.; Klitgaard, K.; Larssen, R.; Fjeldaas, T. Interdigital dermatitis, heel horn erosion, and digital dermatitis in 14 Norwegian dairy herds. J. Dairy Sci. 2013, 96, 7617-7629. [CrossRef] [PubMed]

79. Rasmussen, M.; Capion, N.; Klitgaard, K.; Rogdo, T.; Fjeldaas, T.; Boye, M.; Jensen, T.K. Bovine digital dermatitis: Possible pathogenic consortium consisting of Dichelobacter nodosus and multiple Treponema species. Vet. Microbiol. 2012, 160, 151-161. [CrossRef]

80. Alsaaod, M.; Locher, I.; Jores, J.; Grimm, P.; Brodard, I.; Steiner, A.; Kuhnert, P. Detection of specific Treponema species and Dichelobacter nodosus from digital dermatitis (Mortellaro's disease) lesions in Swiss cattle. Schweiz. Arch. Tierheilkd. 2019, 161, 207-215. [CrossRef] [PubMed]

81. Sobhy, N.M.; Mahmmod, Y.S.; Refaai, W.; Awad, A. Molecular detection of Treponema species organisms in foremilk and udder cleft skin of dairy cows with digital dermatitis. Trop. Anim. Health Prod. 2020, 52, 815-821. [CrossRef] [PubMed]

82. Abebe, R.; Hatiya, H.; Abera, M.; Megersa, B.; Asmare, K. Bovine mastitis: Prevalence, risk factors and isolation of Staphylococcus aureus in dairy herds at Hawassa milk shed, South Ethiopia. BMC Vet. Res. 2016, 12, 270. [CrossRef]

83. Hoque, M.N.; Istiaq, A.; Clement, R.A.; Gibson, K.M.; Saha, O.; Islam, O.K.; Abir, R.A.; Sultana, M.; Siddiki, A.; Crandall, K.A. Insights Into the Resistome of Bovine Clinical Mastitis Microbiome, a Key Factor in Disease Complication. Front. Microbiol. 2020, 11, 860. [CrossRef]

84. Ashraf, A.; Imran, M. Diagnosis of bovine mastitis: From laboratory to farm. Trop. Anim. Health Prod. 2018, 50, 1193-1202. [CrossRef] 
85. Dalanezi, F.; Joaquim, S.; Guimarães, F.; Guerra, S.; Lopes, B.; Schmidt, E.; Cerri, R.; Langoni, H. Influence of pathogens causing clinical mastitis on reproductive variables of dairy cows. J. Dairy Sci. 2020, 103, 3648-3655. [CrossRef]

86. Vakkamäki, J.; Taponen, S.; Heikkilä, A.-M.; Pyörälä, S. Bacteriological etiology and treatment of mastitis in Finnish dairy herds. Acta Vet. Scand. 2017, 59, 1-9. [CrossRef]

87. Hoque, M.N.; Istiaq, A.; Clement, R.A.; Sultana, M.; Crandall, K.A.; Siddiki, A.Z.; Hossain, M.A. Association of milk microbiome in bovine clinical mastitis and their functional implications in cows in Bangladesh. bioRxiv 2019, 591982. [CrossRef]

88. Hoque, M.N.; Istiaq, A.; Clement, R.A.; Sultana, M.; Crandall, K.A.; Siddiki, A.Z.; Hossain, M.A. Metagenomic deep sequencing reveals association of microbiome signature with functional biases in bovine mastitis. Sci. Rep. 2019, 9, 1-14. [CrossRef] [PubMed]

89. Rainard, P. Mammary microbiota of dairy ruminants: Fact or fiction? Vet. Res. 2017, 48, 25. [CrossRef] [PubMed]

90. Taponen, S.; McGuinness, D.; Hiitiö, H.; Simojoki, H.; Zadoks, R.; Pyörälä, S. Bovine milk microbiome: A more complex issue than expected. Vet. Res. 2019, 50, 44. [CrossRef]

91. Ganda, E.K.; Bisinotto, R.S.; Lima, S.F.; Kronauer, K.; Decter, D.H.; Oikonomou, G.; Schukken, Y.H.; Bicalho, R.C. Longitudinal metagenomic profiling of bovine milk to assess the impact of intramammary treatment using a third-generation cephalosporin. Sci. Rep. 2016, 6, 37565. [CrossRef]

92. Derakhshani, H.; Fehr, K.B.; Sepehri, S.; Francoz, D.; De Buck, J.; Barkema, H.W.; Plaizier, J.C.; Khafipour, E. Invited review: Microbiota of the bovine udder: Contributing factors and potential implications for udder health and mastitis susceptibility. J. Dairy Sci. 2018, 101, 10605-10625. [CrossRef]

93. Derakhshani, H.; Plaizier, J.C.; De Buck, J.; Barkema, H.W.; Khafipour, E. Composition and co-occurrence patterns of the microbiota of different niches of the bovine mammary gland: Potential associations with mastitis susceptibility, udder inflammation, and teat-end hyperkeratosis. Anim. Microbiome 2020, 2, 1-17. [CrossRef]

94. Hu, X.; Guo, J.; Mu, R.; Jiang, P.; Zhao, C.; Cao, Y.; Zhang, N.; Fu, Y. The Correlation and Mechanism between Rumen Microbiota Disturbance and Mastitis in Dairy Cows. 2020. Available online: https://www.researchsquare.com/article/rs-32289/v1 (accessed on 1 May 2020).

95. Ma, C.; Sun, Z.; Zeng, B.; Huang, S.; Zhao, J.; Zhang, Y.; Su, X.; Xu, J.; Wei, H.; Zhang, H. Cow-to-mouse fecal transplantations suggest intestinal microbiome as one cause of mastitis. Microbiome 2018, 6, 1-17. [CrossRef]

96. Hu, X.; Guo, J.; Zhao, C.; Jiang, P.; Maimai, T.; Yanyi, L.; Cao, Y.; Fu, Y.; Zhang, N. The gut microbiota contributes to the development of Staphylococcus aureus-induced mastitis in mice. ISME J. 2020, 14, 1-14. [CrossRef]

97. $\mathrm{Hu}, \mathrm{X} . ; \mathrm{Li}, \mathrm{S}$.; Fu, Y.; Zhang, N. Targeting gut microbiota as a possible therapy for mastitis. Eur. J. Clin. Microbiol. Infect. Dis. 2019, 38, 1409-1423. [CrossRef]

98. Rathnaiah, G.; Zinniel, D.K.; Bannantine, J.P.; Stabel, J.R.; Gröhn, Y.T.; Collins, M.T.; Barletta, R.G. Pathogenesis, molecular genetics, and genomics of Mycobacterium avium subsp. paratuberculosis, the etiologic agent of Johne's disease. Front. Vet. Sci. 2017, 4, 187. [CrossRef] [PubMed]

99. Shoyama, F.M.; Janetanakit, T.; Bannantine, J.P.; Barletta, R.G.; Sreevatsan, S. Elucidating the Regulon of a Fur-like Protein in Mycobacterium avium subsp. paratuberculosis (MAP). Front. Microbiol. 2020, 11, 598. [CrossRef]

100. Britton, L.E.; Cassidy, J.P.; O'Donovan, J.; Gordon, S.V.; Markey, B. Potential application of emerging diagnostic techniques to the diagnosis of bovine Johne's disease (paratuberculosis). Vet. J. 2016, 209, 32-39. [CrossRef] [PubMed]

101. Eslami, M.; Shafiei, M.; Ghasemian, A.; Valizadeh, S.; Al-Marzoqi, A.H.; Shokouhi Mostafavi, S.K.; Nojoomi, F.; Mirforughi, S.A. Mycobacterium avium paratuberculosis and Mycobacterium avium complex and related subspecies as causative agents of zoonotic and occupational diseases. J. Cell. Physiol. 2019, 234, 12415-12421. [CrossRef] [PubMed]

102. Pierce, E.S. Could Mycobacterium avium subspecies paratuberculosis cause Crohn's disease, ulcerative colitis ... and colorectal cancer? Infect. Agents Cancer 2018, 13, 1-6. [CrossRef]

103. Torres, J.; Mehandru, S.; Colombel, J.-F.; Peyrin-Biroulet, L. Crohn's disease. Lancet 2017, 389, 1741-1755. [CrossRef]

104. Timms, V.J.; Daskalopoulos, G.; Mitchell, H.M.; Neilan, B.A. The association of Mycobacterium avium subsp. paratuberculosis with inflammatory bowel disease. PLoS ONE 2016, 11, e0148731. [CrossRef]

105. Fecteau, M.-E.; Pitta, D.W.; Vecchiarelli, B.; Indugu, N.; Kumar, S.; Gallagher, S.C.; Fyock, T.L.; Sweeney, R.W. Dysbiosis of the fecal microbiota in cattle infected with Mycobacterium avium subsp. paratuberculosis. PLoS ONE 2016, 11, e0160353. [CrossRef]

106. Sheldon, I.M.; Cronin, J.G.; Bromfield, J.J. Tolerance and innate immunity shape the development of postpartum uterine disease and the impact of endometritis in dairy cattle. Annu. Rev. Anim. Biosci. 2019, 7, 361-384. [CrossRef]

107. Sheldon, I.M.; Owens, S.E. Postpartum uterine infection and endometritis in dairy cattle. Anim. Reprod. 2018, 14, 622-629. [CrossRef]

108. Mohammed, Z.; Mann, G.; Robinson, R. Impact of endometritis on post-partum ovarian cyclicity in dairy cows. Vet. J. 2019, 248, 8-13. [CrossRef] [PubMed]

109. Machado, V.; Bicalho, R. The infectious disease epidemiologic triangle of bovine uterine diseases. Anim. Reprod. 2018, 12, 450-464

110. Knudsen, L.R.V.; Karstrup, C.C.; Pedersen, H.G.; Angen, Ø.; Agerholm, J.S.; Rasmussen, E.L.; Jensen, T.K.; Klitgaard, K. An investigation of the microbiota in uterine flush samples and endometrial biopsies from dairy cows during the first 7 weeks postpartum. Theriogenology 2016, 86, 642-650. [CrossRef] [PubMed]

111. Galvão, K.N.; Bicalho, R.C.; Jeon, S.J. Symposium review: The uterine microbiome associated with the development of uterine disease in dairy cows. J. Dairy Sci. 2019, 102, 11786-11797. [CrossRef] [PubMed]

112. de Oliveira, E.; Cunha, F.; Daetz, R.; Figueiredo, C.; Chebel, R.; Santos, J.; Risco, C.; Jeong, K.; Machado, V.; Galvão, K. Using chitosan microparticles to treat metritis in lactating dairy cows. J. Dairy Sci. 2020, 103, 7377-7391. [CrossRef] 
113. Adnane, M.; Kaidi, R.; Hanzen, C.; England, G.C. Risk factors of clinical and subclinical endometritis in cattle: A review. Turk. J. Vet. Anim. Sci. 2017, 41,1-11. [CrossRef]

114. Bicalho, M.; Santin, T.; Rodrigues, M.; Marques, C.; Lima, S.; Bicalho, R. Dynamics of the microbiota found in the vaginas of dairy cows during the transition period: Associations with uterine diseases and reproductive outcome. J. Dairy Sci. 2017, 100, 3043-3058. [CrossRef]

115. Jeon, S.J.; Vieira-Neto, A.; Gobikrushanth, M.; Daetz, R.; Mingoti, R.D.; Parize, A.C.B.; de Freitas, S.L.; da Costa, A.N.L.; Bicalho, R.C.; Lima, S. Uterine microbiota progression from calving until establishment of metritis in dairy cows. Appl. Environ. Microbiol. 2015, 81, 6324-6332. [CrossRef]

116. Miranda-CasoLuengo, R.; Lu, J.; Williams, E.J.; Miranda-CasoLuengo, A.A.; Carrington, S.D.; Evans, A.C.; Meijer, W.G. Delayed differentiation of vaginal and uterine microbiomes in dairy cows developing postpartum endometritis. PLOS ONE 2019, 14, e0200974. [CrossRef]

117. Wang, M.-L.; Liu, M.-C.; Xu, J.; An, L.-G.; Wang, J.-F.; Zhu, Y.-H. Uterine microbiota of dairy cows with clinical and subclinical endometritis. Front. Microbiol. 2018, 9, 2691. [CrossRef]

118. Piersanti, R.L.; Zimpel, R.; Molinari, P.C.; Dickson, M.J.; Ma, Z.; Jeong, K.C.; Santos, J.E.; Sheldon, I.M.; Bromfield, J.J. A model of clinical endometritis in Holstein heifers using pathogenic Escherichia coli and Trueperella pyogenes. J. Dairy Sci. 2019, 102, 2686-2697. [CrossRef]

119. Carneiro, L.C.; Cronin, J.G.; Sheldon, I.M. Mechanisms linking bacterial infections of the bovine endometrium to disease and infertility. Reprod. Biol. 2016, 16, 1-7. [CrossRef] [PubMed]

120. Zhao, C.; Liu, G.; Li, X.; Guan, Y.; Wang, Y.; Yuan, X.; Sun, G.; Wang, Z.; Li, X. Inflammatory mechanism of rumenitis in dairy cows with subacute ruminal acidosis. BMC Vet. Res. 2018, 14, 135. [CrossRef] [PubMed]

121. Pechová, A.; Nečasová, A. The relationship between subclinical ketosis and ruminal dysfunction in dairy cows. Ann. Anim. Sci. 2018, 18, 955-971. [CrossRef]

122. Elghandour, M.M.; Khusro, A.; Adegbeye, M.J.; Tan, Z.; Abu Hafsa, S.; Greiner, R.; Ugbogu, E.; Anele, U.Y.; Salem, A. Dynamic role of single-celled fungi in ruminal microbial ecology and activities. J. Appl. Microbiol. 2020, 128, 950-965. [CrossRef] [PubMed]

123. Abdela, N. Sub-acute ruminal acidosis (SARA) and its consequence in dairy cattle: A review of past and recent research at global prospective. Achiev. Life Sci. 2016, 10, 187-196. [CrossRef]

124. Mohammed, R.; Vyas, D.; Yang, W.; Beauchemin, K. Changes in the relative population size of selected ruminal bacteria following an induced episode of acidosis in beef heifers receiving viable and non-viable active dried yeast. J. Appl. Microbiol. 2017, 122, 1483-1496. [CrossRef]

125. Khafipour, E.; Li, S.; Tun, H.; Derakhshani, H.; Moossavi, S.; Plaizier, J. Effects of grain feeding on microbiota in the digestive tract of cattle. Anim. Front. 2016, 6, 13-19. [CrossRef]

126. Plaizier, J.C.; Li, S.; Tun, H.M.; Khafipour, E. Nutritional models of experimentally-induced subacute ruminal acidosis (SARA) differ in their impact on rumen and hindgut bacterial communities in dairy cows. Front. Microbiol. 2017, 7, 2128. [CrossRef]

127. Ogunade, I.; Pech-Cervantes, A.; Schweickart, H. Metatranscriptomic analysis of sub-acute ruminal acidosis in beef cattle. Animals 2019, 9, 232. [CrossRef]

128. Zeineldin, M.; Barakat, R.; Elolimy, A.; Salem, A.Z.; Elghandour, M.M.; Monroy, J.C. Synergetic action between the rumen microbiota and bovine health. Microb. Pathog. 2018, 124, 106-115. [CrossRef]

129. Brown, D. Optimising rumen health and the effect this will have on ketosis. Livestock 2018, 23, 174-178. [CrossRef]

130. Kroezen, V.; Miglior, F.; Schenkel, F.; Squires, J. Development of a genetic marker panel for ketosis in dairy cattle. J. Anim. Sci. 2016, 94, 233-234. [CrossRef]

131. Rodriguez-Jimenez, S.; Haerr, K.; Trevisi, E.; Loor, J.; Cardoso, F.; Osorio, J. Prepartal standing behavior as a parameter for early detection of postpartal subclinical ketosis associated with inflammation and liver function biomarkers in peripartal dairy cows. $J$. Dairy Sci. 2018, 101, 8224-8235. [CrossRef] [PubMed]

132. Canning, P.C.; Srinagesh, S.; Manibusan, A.; Pinkstaff, J.; Knudsen, N. Bovine fibroblast growth factor 21 and ketosis in dairy cattle. U. S. Pat. Appl. Publ. 2019, 16, 325-345.

133. Huang, Y.; Li, Y.; He, B.; Hu, J.; Ali Mohsin, M.; Yu, H.; Wang, P.; Zhang, P.; Du, Y.; Huang, L. The Influence of Ketosis on the Rectal Microbiome of Chinese Holstein Cows. Pak. Vet. J. 2019, 39, 175-180. [CrossRef]

134. Hill, C.; Guarner, F.; Reid, G.; Gibson, G.R.; Merenstein, D.J.; Pot, B.; Morelli, L.; Canani, R.B.; Flint, H.J.; Salminen, S. The International Scientific Association for Probiotics and Prebiotics consensus statement on the scope and appropriate use of the term probiotic. Nat. Rev. Gastroenterol. Hepatol. 2014, 11, 506-514. [CrossRef]

135. Wan, M.L.Y.; Forsythe, S.J.; El-Nezami, H. Probiotics interaction with foodborne pathogens: A potential alternative to antibiotics and future challenges. Crit. Rev. Food Sci. Nutr. 2019, 59, 3320-3333. [CrossRef]

136. Gao, J.; Li, Y.; Wan, Y.; Hu, T.; Liu, L.; Yang, S.; Gong, Z.; Zeng, Q.; Wei, Y.; Yang, W. A novel postbiotic from Lactobacillus rhamnosus GG with a beneficial effect on intestinal barrier function. Front. Microbiol. 2019, 10, 477. [CrossRef]

137. Collins, F.W.; Rea, M.C.; Hill, C.; Ross, R.P. 11 Antimicrobials from Lactic. Lactic Acid Bacteria: Microbiological and Functional Aspects. In Lactic Acid Bacteria; Vinderola, G., Ouwehand, A., Salminen, S., von Wright, A., Eds.; CRC Press: Boca Raton, FL, USA, 2019; pp. 151-174.

138. Anas, M.; Ahmed, K.; Mebrouk, K. Study of the antimicrobial and probiotic effect of Lactobacillus plantarum isolated from raw goat's milk from the region of Western Algeria. Int. J. Sci. Es Basic Appl. Res. 2014, 13, $18-27$. 
139. Sanders, M.E.; Merenstein, D.J.; Reid, G.; Gibson, G.R.; Rastall, R.A. Probiotics and prebiotics in intestinal health and disease: From biology to the clinic. Nat. Rev. Gastroenterol. Hepatol. 2019, 16, 605-616. [CrossRef]

140. Uyeno, Y.; Shigemori, S.; Shimosato, T. Effect of probiotics/prebiotics on cattle health and productivity. Microbes Environ. 2015, ME14176. [CrossRef] [PubMed]

141. Suryadi, U.; Nugraheni, Y.R.; Prasetyo, A.F.; Awaludin, A. Evaluation of effects of a novel probiotic feed supplement on the quality of broiler meat. Vet. World 2019, 12, 1775. [CrossRef]

142. Goto, H.; Qadis, A.Q.; Kim, Y.-H.; Ikuta, K.; Ichijo, T.; Sato, S. Effects of a bacterial probiotic on ruminal pH and volatile fatty acids during subacute ruminal acidosis (SARA) in cattle. J. Vet. Med. Sci. 2016, 16-0211. [CrossRef] [PubMed]

143. Rainard, P.; Foucras, G. A critical appraisal of probiotics for mastitis control. Front. Vet. Sci. 2018, 5, 251. [CrossRef] [PubMed]

144. Angelopoulou, A.; Warda, A.K.; Hill, C.; Ross, R.P. Non-antibiotic microbial solutions for bovine mastitis-live biotherapeutics, bacteriophage, and phage lysins. Crit. Rev. Microbiol. 2019, 45, 564-580. [CrossRef] [PubMed]

145. Pellegrino, M.; Berardo, N.; Giraudo, J.; Nader-Macías, M.; Bogni, C. Bovine mastitis prevention: Humoral and cellular response of dairy cows inoculated with lactic acid bacteria at the dry-off period. Benef. Microbes 2017, 8, 589-596. [CrossRef]

146. Souza, R.F.S.; Rault, L.; Seyffert, N.; Azevedo, V.; Le Loir, Y.; Even, S. Lactobacillus casei BL23 modulates the innate immune response in Staphylococcus aureus-stimulated bovine mammary epithelial cells. Benef. Microbes 2018, 9, 985-995. [CrossRef]

147. Wallis, J.K.; Krömker, V.; Paduch, J.-H. Biofilm formation and adhesion to bovine udder epithelium of potentially probiotic lactic acid bacteria. AIMS Microbiol. 2018, 4, 209. [CrossRef]

148. Wallis, J.K.; Krömker, V.; Paduch, J.-H. Biofilm challenge: Lactic acid bacteria isolated from bovine udders versus Staphylococci. Foods 2019, 8, 79. [CrossRef]

149. Armas, F.; Camperio, C.; Marianelli, C. In vitro assessment of the probiotic potential of Lactococcus lactis LMG 7930 against ruminant mastitis-causing pathogens. PLoS ONE 2017, 12, e0169543. [CrossRef] [PubMed]

150. Pellegrino, M.S.; Frola, I.D.; Natanael, B.; Gobelli, D.; Nader-Macias, M.E.; Bogni, C.I. In vitro characterization of lactic acid bacteria isolated from bovine milk as potential probiotic strains to prevent bovine mastitis. Probiotics Antimicrob. Proteins 2019, 11, 74-84. [CrossRef] [PubMed]

151. Yu, J.; Ren, Y.; Xi, X.; Huang, W.; Zhang, H. A novel lactobacilli-based teat disinfectant for improving bacterial communities in the milks of cow teats with subclinical mastitis. Front. Microbiol. 2017, 8, 1782. [CrossRef] [PubMed]

152. Amat, S.; Alexander, T.W.; Holman, D.B.; Schwinghamer, T.; Timsit, E. Intranasal Bacterial Therapeutics Reduce Colonization by the Respiratory Pathogen Mannheimia haemolytica in Dairy Calves. Msystems 2020, 5, e00629-19. [CrossRef] [PubMed]

153. Lu, S.; Nie, Y.; Wang, M.; Xu, H.-X.; Ma, D.-L.; Liang, J.-L.; Wu, X.-L. Mono-homologous linear DNA recombination by the non-homologous end-joining pathway as a novel and simple gene inactivation method: A proof of concept study in Dietzia sp. DQ12-45-1b. bioRxiv 2018, 300723. [CrossRef]

154. Click, R.E. A 60-day probiotic protocol with Dietzia subsp. C79793-74 prevents development of Johne's disease parameters after in utero and/or neonatal MAP infection. Virulence 2011, 2, 337-347. [CrossRef] [PubMed]

155. Da Silva Sabo, S.; Villalobos, E.F.; Meireles, A.C. Impact of Probiotics on Animal Health. Lactic Acid Bacteria: A Functional Approach; CRC Press: Boca Raton, FL, USA, 2020; pp. 261-290. [CrossRef]

156. Appiah, M.O.; Wang, J.; Lu, W. Microflora in the Reproductive Tract of Cattle: A Review (Running Title: The Microflora and Bovine Reproductive Tract). Agriculture 2020, 10, 232. [CrossRef]

157. Deng, Q.; Odhiambo, J.F.; Farooq, U.; Lam, T.; Dunn, S.M.; Ametaj, B.N. Intravaginal lactic acid bacteria modulated local and systemic immune responses and lowered the incidence of uterine infections in periparturient dairy cows. PLoS ONE 2015, 10, e0124167. [CrossRef]

158. Genís, S.; Bach, À.; Fàbregas, F.; Arís, A. Potential of lactic acid bacteria at regulating Escherichia coli infection and inflammation of bovine endometrium. Theriogenology 2016, 85, 625-637. [CrossRef]

159. Genís, S.; Sánchez-Chardi, A.; Bach, À.; Fàbregas, F.; Arís, A. A combination of lactic acid bacteria regulates Escherichia coli infection and inflammation of the bovine endometrium. J. Dairy Sci. 2017, 100, 479-492. [CrossRef]

160. Boranbayeva, T.; Karahan, A.G.; Tulemissova, Z.; Myktybayeva, R.; Özkaya, S. Properties of a New Probiotic Candidate and Lactobacterin-TK 2 Against Diarrhea in Calves. Probiotics Antimicrob. Proteins 2020, 12, 918-928. [CrossRef] [PubMed]

161. Fukuda, T.; Otsuka, M.; Nishi, K.; Nishi, Y.; Tsukano, K.; Noda, J.; Higuchi, H.; Suzuki, K. Evaluation of probiotic therapy for calf diarrhea with serum diamine oxidase activity as an indicator. Jpn. J. Vet. Res. 2019, 67, 305-311.

162. Renaud, D.; Kelton, D.; Weese, J.; Noble, C.; Duffield, T. Evaluation of a multispecies probiotic as a supportive treatment for diarrhea in dairy calves: A randomized clinical trial. J. Dairy Sci. 2019, 102, 4498-4505. [CrossRef] [PubMed]

163. Maldonado, N.C.; Chiaraviglio, J.; Bru, E.; De Chazal, L.; Santos, V.; Nader-Macías, M. Effect of milk fermented with lactic acid bacteria on diarrheal incidence, growth performance and microbiological and blood profiles of newborn dairy calves. Probiotics Antimicrob. Proteins 2018, 10, 668-676. [CrossRef] [PubMed]

164. Jamal, M.; Bukhari, S.M.; Andleeb, S.; Ali, M.; Raza, S.; Nawaz, M.A.; Hussain, T.; Rahman, S.U.; Shah, S.S. Bacteriophages: An overview of the control strategies against multiple bacterial infections in different fields. J. Basic Microbiol. 2019, 59, 123-133. [CrossRef]

165. Altamirano, F.L.G.; Barr, J.J. Phage therapy in the postantibiotic era. Clin. Microbiol. Rev. 2019, 32, e00066-18.

166. Liang, X.; Radosevich, M. Commentary: A host-produced quorum-sensing autoinducer controls a phage lysis-lysogeny decision. Front. Microbiol. 2019, 10, 1201. [CrossRef]

167. Dion, M.B.; Oechslin, F.; Moineau, S. Phage diversity, genomics and phylogeny. Nat. Rev. Microbiol. 2020, 18, 125-138. [CrossRef] 
168. Kortright, K.E.; Chan, B.K.; Koff, J.L.; Turner, P.E. Phage therapy: A renewed approach to combat antibiotic-resistant bacteria. Cell Host Microbe 2019, 25, 219-232. [CrossRef]

169. Górski, A.; Międzybrodzki, R.; Borysowski, J. Phage Therapy: A Practical Approach; Springer: Cham, Switzerland, 2019.

170. Zduńczyk, S.; Janowski, T. Bacteriophages and associated endolysins in therapy and prevention of mastitis and metritis in cows: Current knowledge. Anim. Reprod. Sci. 2020, 218, 106504. [CrossRef]

171. Hamza, A.; Perveen, S.; Abbas, Z.; Rehman, S.U. The lytic SA phage demonstrate bactericidal activity against mastitis causing Staphylococcus aureus. Open Life Sci. 2016, 11, 39-45. [CrossRef]

172. Tahir, A.; Asif, M.; Abbas, Z.; ur Rehman, S. Three bacteriophages SA, SA2 and SNAF can control growth of milk isolated Staphylococcal species. Pak. J. Zool. 2017, 49, 425-759. [CrossRef]

173. Ganaie, M.; Qureshi, S.; Kashoo, Z.; Wani, S.; Hussain, M.; Kumar, R.; Maqbool, R.; Sikander, P.; Banday, M.; Malla, W. Isolation and characterization of two lytic bacteriophages against Staphylococcus aureus from India: Newer therapeutic agents against Bovine mastitis. Vet. Res. Commun. 2018, 42, 289-295. [CrossRef] [PubMed]

174. Titze, I.; Lehnherr, T.; Lehnherr, H.; Krömker, V. Efficacy of bacteriophages against Staphylococcus aureus isolates from bovine mastitis. Pharmaceuticals 2020, 13, 35. [CrossRef]

175. Iwano, H.; Inoue, Y.; Takasago, T.; Kobayashi, H.; Furusawa, T.; Taniguchi, K.; Fujiki, J.; Yokota, H.; Usui, M.; Tanji, Y Bacteriophage $\Phi S A 012$ has a broad host range against Staphylococcus aureus and effective lytic capacity in a mouse mastitis model. Biology 2018, 7, 8. [CrossRef]

176. Geng, H.; Zou, W.; Zhang, M.; Xu, L.; Liu, F.; Li, X.; Wang, L.; Xu, Y. Evaluation of phage therapy in the treatment of Staphylococcus aureus-induced mastitis in mice. Folia Microbiol. 2020, 65, 339-351. [CrossRef]

177. Porter, J.; Anderson, J.; Carter, L.; Donjacour, E.; Paros, M. In vitro evaluation of a novel bacteriophage cocktail as a preventative for bovine coliform mastitis. J. Dairy Sci. 2016, 99, 2053-2062. [CrossRef]

178. Da Silva Duarte, V.; Dias, R.S.; Kropinski, A.M.; Campanaro, S.; Treu, L.; Siqueira, C.; Vieira, M.S.; da Silva Paes, I.; Santana, G.R.; Martins, F. Genomic analysis and immune response in a murine mastitis model of vB_EcoM-UFV13, a potential biocontrol agent for use in dairy cows. Sci. Rep. 2018, 8, 1-12. [CrossRef]

179. Da Silva Duarte, V.; Dias, R.S.; Kropinski, A.M.; da Silva Xavier, A.; Ferro, C.G.; Vidigal, P.M.; da Silva, C.C.; de Paula, S.O. A T4virus prevents biofilm formation by Trueperella pyogenes. Vet. Microbiol. 2018, 218, 45-51. [CrossRef]

180. Zhou, Y.; Zhang, H.; Bao, H.; Wang, X.; Wang, R. The lytic activity of recombinant phage lysin LysK $\Delta$ amidase against staphylococcal strains associated with bovine and human infections in the Jiangsu province of China. Res. Vet. Sci. 2017, 111, 113-119. [CrossRef]

181. Fan, J.; Zeng, Z.; Mai, K.; Yang, Y.; Feng, J.; Bai, Y.; Sun, B.; Xie, Q.; Tong, Y.; Ma, J. Preliminary treatment of bovine mastitis caused by Staphylococcus aureus, with trx-SA1, recombinant endolysin of S. aureus bacteriophage IME-SA1. Vet. Microbiol. 2016, 191, 65-71. [CrossRef]

182. Scholte, C.; Nelson, D.; Garcia, M.; Linden, S.; Elsasser, T.; Kahl, S.; Qu, Y.; Moyes, K. Recombinant bacteriophage endolysin PlyC is nontoxic and does not alter blood neutrophil oxidative response in lactating dairy cows. J. Dairy Sci. 2018, 101, 6419-6423. [CrossRef]

183. Frizzo, L.S.; Signorini, M.L.; Rosmini, M.R. Probiotics and prebiotics for the health of cattle. In Probiotics and Prebiotics in Animal Health and Food Safety; Di Gioia, D., Biavati, B., Eds.; Springer: Cham, Switzerland, 2018; pp. 155-174.

184. Smulski, S.; Turlewicz-Podbielska, H.; Wylandowska, A.; Włodarek, J. Non-antibiotic possibilities in prevention and treatment of calf diarrhoea. J. Vet. Res. 2020, 64, 119-126. [CrossRef]

185. Singh, A.; Kerketta, S.; Yogi, R.; Kumar, A.; Ojha, L. Prebiotics: The new feed supplement for dairy calf. Int. J. Livest Res. 2017, 7, 1-17. [CrossRef]

186. Grispoldi, L.; Bertero, F.; Franceschini, S.; Mastrosimone, F.; Sechi, P.; Iulietto, M.F.; Ceccarelli, M.; Cenci-Goga, B.T. Prevalence and characterisation of shigatoxigenic Escherichia coli isolated from beef cattle fed with prebiotics. Ital. J. Food Saf. 2017, 6, 4. [CrossRef]

187. Al-Shawi, S.G.; Dang, D.S.; Yousif, A.Y.; Al-Younis, Z.K.; Najm, T.A.; Matarneh, S.K. The Potential Use of Probiotics to Improve Animal Health, Efficiency, and Meat Quality: A Review. Agriculture 2020, 10, 452. [CrossRef]

188. Klein-Jöbstl, D.; Schornsteiner, E.; Mann, E.; Wagner, M.; Drillich, M.; Schmitz-Esser, S. Pyrosequencing reveals diverse fecal microbiota in Simmental calves during early development. Front. Microbiol. 2014, 5, 622.

189. Oikonomou, G.; Teixeira, A.G.V.; Foditsch, C.; Bicalho, M.L.; Machado, V.S.; Bicalho, R.C. Fecal microbial diversity in pre-weaned dairy calves as described by pyrosequencing of metagenomic $16 \mathrm{~S}$ rDNA. Associations of Faecalibacterium species with health and growth. PLoS ONE 2013, 8, e63157. [CrossRef] 